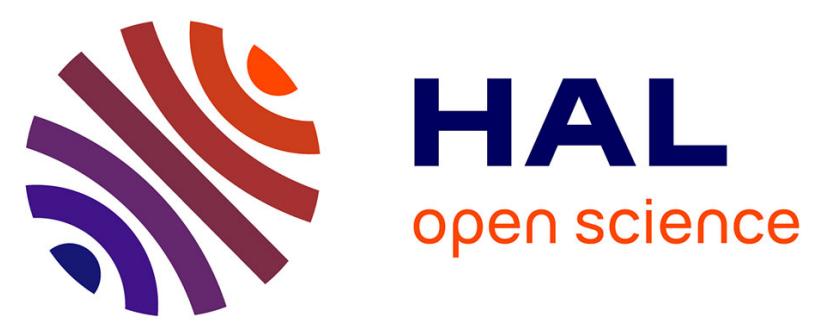

\title{
Synthesis and Anticancer Activity of Gold Porphyrin Linked to Malonate Diamine Platinum Complexes
} Isabelle Toubia, Christophe Nguyen, Stéphane Diring, Lamiaa Ali, Ludivine Larue, Rabab Aoun, Céline Frochot, Magali Gary-Bobo, Marwan Kobeissi, Fabrice Odobel

\section{To cite this version:}

Isabelle Toubia, Christophe Nguyen, Stéphane Diring, Lamiaa Ali, Ludivine Larue, et al.. Synthesis and Anticancer Activity of Gold Porphyrin Linked to Malonate Diamine Platinum Complexes. Inorganic Chemistry, 2019, 58 (18), pp.12395-12406. 10.1021/acs.inorgchem.9b01981 . hal-03015360

\section{HAL Id: hal-03015360 https://hal.science/hal-03015360}

Submitted on 19 Nov 2020

HAL is a multi-disciplinary open access archive for the deposit and dissemination of scientific research documents, whether they are published or not. The documents may come from teaching and research institutions in France or abroad, or from public or private research centers.
L'archive ouverte pluridisciplinaire HAL, est destinée au dépôt et à la diffusion de documents scientifiques de niveau recherche, publiés ou non, émanant des établissements d'enseignement et de recherche français ou étrangers, des laboratoires publics ou privés. 


\section{Synthesis and anticancer activity of gold porphyrin linked to malonate diamine platinum complexes}

Isabelle Toubia, ${ }^{\text {ad\# }}$ Christophe Nguyen, ${ }^{\mathrm{b} \#}$ Stéphane Diring, ${ }^{a}$ Lamiaa M. A. Ali, ${ }^{\mathrm{b}}$ Ludivine Larue ${ }^{\mathrm{c}}$, Rabab Aoun, ${ }^{d}$ Céline Frochot, ${ }^{* c}$ Magali Gary-Bobo, ${ }^{* b}$ Marwan Kobeissi, ${ }^{* d}$ Fabrice Odobel*a

${ }^{a}$ CEISAM, Chimie Et Interdisciplinarité, Synthèse, Analyse, Modélisation, CNRS, UMR CNRS 6230, UFR des Sciences et des Techniques ; 2, rue de la Houssinière - BP 92208; 44322 NANTES Cedex 3 (France). E-mail:Fabrice.Odobel@univ-nantes.fr

bIBMM, Institut des Biomolécules Max Mousseron, UMR 5247 CNRS, UM-Faculté de Pharmacie, 15 Avenue Charles 9 Flahault, 34093, Montpellier cedex 05 (France). E-mail: magali.gary-bobo@inserm.fr

'LRGP, Laboratoire Réactions et Génie des Procédés, UMR 7274 CNRS-Université de Lorraine, 1 rue Grandville, 54000 Nancy, France.E-mail : celine.frochot@univ-lorraine.fr

${ }^{d}$ LaboratoireRammalRammal, Equipe de Synthèse Organique Appliquée SOA, Université Libanaise, Faculté des Sciences 5, Nabatieh, Liban. E-mail: mkobeissi@ul.edu.lb

"These authors contributed equally to this study.

\section{Synopsis}

Novel anticancer agents containing a gold porphyrin appended to a platinum complex were synthesized and characterized. Interestingly, the heterobimetallic conjugates showed enhanced cytotoxic activity due to cooperative effects from the two metals in addition to selectivity to cancer cells. 


\begin{abstract}
Recently, Gold(III) porphyrins have gained great interest as anticancer drugs not only for stability of gold(III), but also for the functionalization of porphyrin to allow bridging with another metal such as platinum(II). We report here, for the first time, the synthesis of three new bi-metal compounds containing gold(III) porphyrin conjugated to a platinum diamine moiety through malonate bridging to obtain enhanced cytotoxicity from both metals combined to the phototoxicity of the porphyrin. The three complexes differ by type of diamine ligands around platinum(II) which are ammonia $\left(\mathrm{NH}_{3}\right)$, cyclohexane diamine (CyDA) and pyridine methyl amine (Py). The synthesis was carried out using complexation of activated malonic acid derivatives with aqua diamino-platinum(II) complexes and the products were characterized by IR, NMR, mass spectra and by elementary analysis. Cytotoxic activity of the conjugates was screened in both healthy and cancer cell lines, human fibroblast cells (FS-68) and human breast cancer cells (MCF-7), and was compared to the corresponding platinum(II) complexes. The cyclohexyldiamine (CyDA) derivative exhibited the most cytotoxic effect among the series. The results showed that gold(III)/Pt(II)conjugates are more potent by 2 to 5.6 -fold than the corresponding platinum complexes. Moreover, the dyad AuP-PtCyDA is $18 \%$ more potent and also more selective towards cancer cells than the parent gold porphyrin substituted with malonic acid. On the other hand, the $I C_{50}$ of dyad AuP-PtCyDA is $43 \%$ lower than that of AuTPP, but more selective towards healthy cells. Singlet oxygen measurements indicated that gold(III) porphyrin derivatives are poor oxygen sensitizers and cell death occurred potentially due to generation of others reactive oxygen species (ROS) upon reductive quenching of the gold porphyrin excited state. In addition, the increase in cancer cell death obtained after light irradiation is totally absent in healthy cells, demonstrating the specificity of this PDT treatment on cancer cells. Our findings imply that the incorporation of two different cytotoxic metals in the same molecule represents a remarkable cytotoxic effect compared to traditional homometallic Pt(II) drugs.
\end{abstract}

\title{
Introduction
}

Cancer still remains one the major cause of mortality in the world in spite of the many progresses made in medical treatments for several decades. Conventional cancer treatment includes surgery, chemotherapy and radiotherapy. Platinum based compounds, such as Cisplatin, are widely used as anticancer therapeutic agents, but they have dose-limiting side effects and some cancer lines have become resistant to these drugs. ${ }^{1}$ 
Photodynamic therapy (PDT) is an approved clinical treatment in oncology. It has many advantages such as low-cost, less invasiveness and minimal side-effects than conventional chemotherapy. ${ }^{2}$ PDT requires a photosensitizer, such as a porphyrin derivatives, which are known to better concentrate within the tumor tissue. ${ }^{3}$ Currently, many porphyrin based photosensitizers are developed used in the clinic. ${ }^{2 c, 34}$ The Photofrin was the first photosensitiser approved by the Food and Drug Administration (FDA) in 1993 for bladder cancer therapy. Now, it is used for several cancers. Then, a second generation of photoactive compounds was produced and developed for clinical use such as Foscan, Metvix, Laserphyrin, Redaporphin. In addition, several compounds such as Tookad, Radachlorin are under clinical trials for cancer treatment. Light excitation of photosensitizers produces reactive oxygen species (ROS) in tumor and ultimately leads to cancer cell death, a method that confers higher selectivity to cancer cells than Cisplatin-based chemotherapy treatments.

The combination of a porphyrin or a phthalocyanine with an appended platinum, ${ }^{5}$ gold,${ }^{6}$ or ruthenium, ${ }^{7}$ complex has been attempted to design innovative anticancer drugs. Interesting synergetic anticancer properties are obtained thanks to the dark chemostatic effect of the metal complex amplified by the PDT effect generated upon light excitation of the porphyrin or the phthalocyanine. ${ }^{5 a}$, ${ }^{b}$ Recently, Che and co-workers reported the great pverotential of cationic gold(III) porphyrins as cytotoxic agent towards various cancer cell lines. ${ }^{8}$ This discovery has stimulated many studies with gold porphyrins to develop anticancer drugs. ${ }^{9}$ Interestingly, while Cisplatin anticancer drugs bind to DNA and induce cell death by binding to purine nucleic bases such as guanine and adenine, ${ }^{1 a}$ gold porphyrins target mitochondria and particularly the heat shock protein. ${ }^{10} \mathrm{As}$ a consequence, the combination of Cisplatin derivative with gold porphyrin could lead to synergistic effect owing to different modes of action.

The most general mechanism of action of PDT is the generation of singlet oxygen by energy transfer from the photosensitizer excited triplet state to the triplet ground state of oxygen (classified as type II mechanism in PDT). It is well-accepted that photosensitizers with triplet excited states are more favorable than singlet ones to sensitize oxygen, because oxygen has a triplet ground state therefore energy transfer process from excited states of similar multiplicity are more efficient. ${ }^{11}$

Gold porphyrins are known to undergo intersystem crossing with unity quantum yield owing to the heavy atom effect induced by the presence of gold. ${ }^{12}$ As a result, itis reasonable to anticipate that gold porphyrins could be promising candidates for PDT, such as it was shown for palladium porphyrins. ${ }^{11 d,}$ eHowever, to the best of our knowledge, there is so far no single study of the phototoxic activity of gold porphyrin derivatives.

In this work, we have investigated the combination of Cisplatin derivatives covalently connected to a gold porphyrin in order to take advantage, on one hand, of the intrinsic cytotoxicity of the platinum complex added to that of the gold porphyrin and, on the other hand, of the potentially 
high phototoxicity of gold porphyrin upon light excitation (Chart 1). In addition, the affinity of porphyrin for tumor cells could also enhance selectivity and concentration of Cisplatin into tumor and thus increase the anticancer activity. However, this affinity is not sufficient legitimating that targeting strategies are currently explored to enhance the selectivity towards cancer cells. ${ }^{13}$ Overall, the gold porphyrin platinum complex conjugates could have superior anticancer activity than individual compounds.

To test this idea, we report herein the preparation and the biological properties of three new dyads composed of gold porphyrin connected to a platinum diamine complex liganded via a malonate anchor (Chart 1). The diamine ligands around platinum(II) used in this work are ammoniac, cyclohexane diamine (CyDA) and pyridine methyl amine (Py).These three amine ligands where selected in this study, because related platinum complexes, such as Cisplatin, Picoplatin and oxaliplatin, have shown effective anticancer activities. ${ }^{1 a}, 5 f, 14$ The three dyads were tested in human healthy and tumor cell lines to quantify their cytotoxicity without light excitation and their phototoxicity under light excitation.

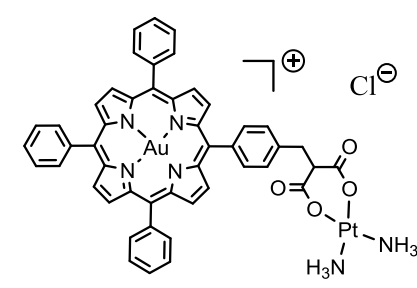

AuP-PtNH ${ }_{3}$

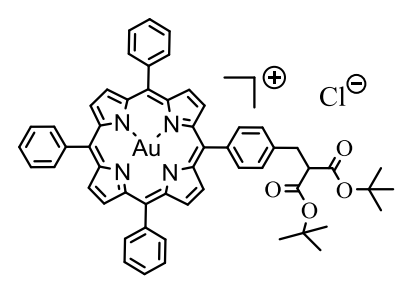

9

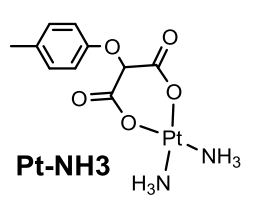

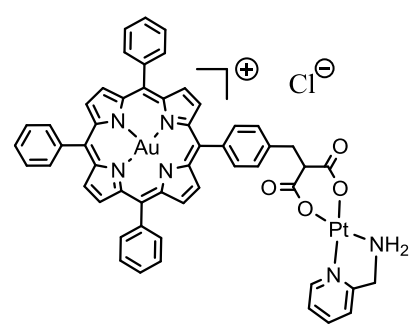

AuP-PtPy

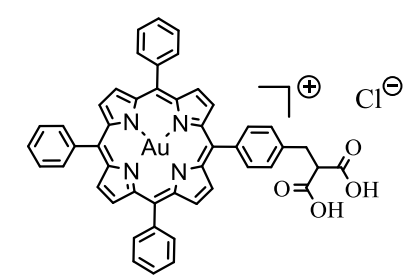

10

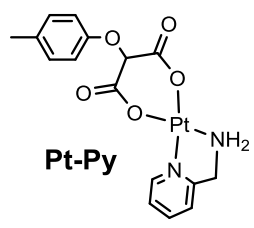

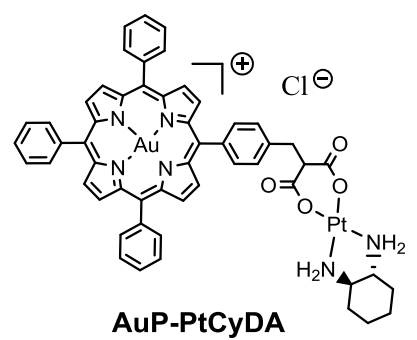

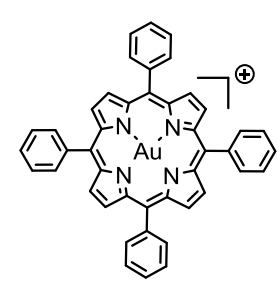

AuTPP

Chart 1. Structures of the compounds investigated in this study.

It was demonstrated that gold(III)/Pt(II)conjugates are more potent by 2 to 5.6 -fold than the corresponding platinum complexes. The cyclohexyldiamine (CyDA) derivative exhibited the most cytotoxic effect among the series. Singlet oxygen measurements indicated that gold(III) porphyrin derivatives are poor oxygen sensitizers and cell death occurred potentially due to generation of others 
reactive oxygen species (ROS) upon reductive quenching of the gold porphyrin excited state. Overall this study indicates that the incorporation of two different cytotoxic metals in the same molecule represents a remarkable cytotoxic effect compared to traditional homometallic Pt(II) drugs and that an increased cancer cell death was obtained after light irradiation only in cancer cells.

\section{Synthesis of the compounds}

The synthesis of the reference platinum compounds ( $\mathbf{P t}-\mathbf{N H}_{3}, \mathbf{P t}-\mathbf{P y}$ and PtCyDA) is illustrated in Scheme 1. First, p-cresol $\mathbf{1}$ was O-alkylated with bromoditertbutyl malonate $\mathbf{2}$ according to a Williamson substitution reaction affording 3 in 36\% yield. We suspect that this lower yield stems from a second O-alkylation of compound $\mathbf{3}$, concomitant with its bromination and further nucleophilic substitution by $p$-cresol as already reported on a similar compound. ${ }^{15}$ The tertbutyl esters of the malonate were subsequently hydrolyzed with trifluoroacetic acid (TFA) to give compound 4. Finally, the dicarboxylato platinum complexes were obtained in 92\% yield according to Dhara's methodology, which consists in activating the carboxylic acid groups by deprotonation using sodium hydroxide before being reacted with the platinum amino precursor containing two weakly bound aqua ligands. ${ }^{14 a}, 16$

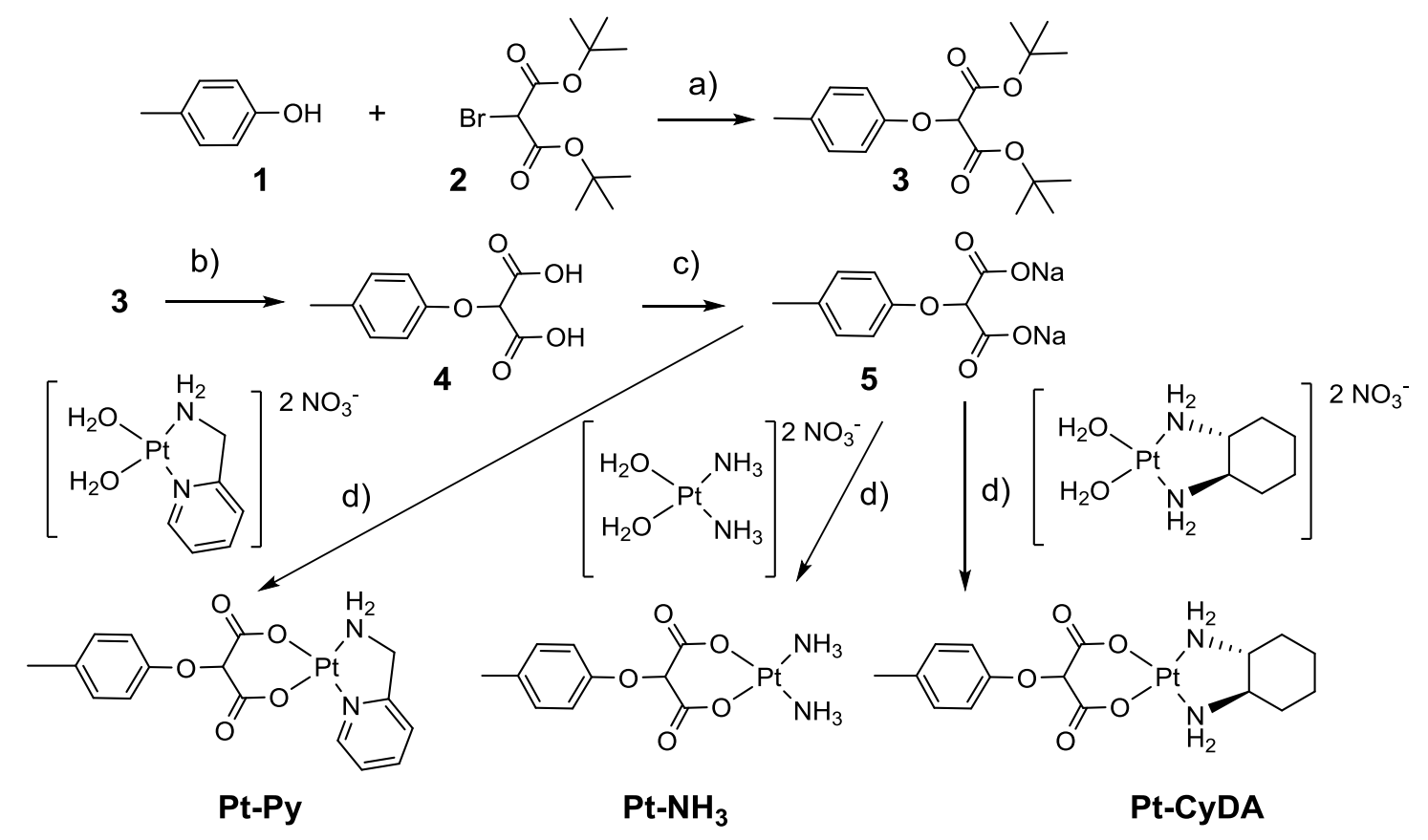

Scheme 1. Synthetic route for the preparation of the reference platinum complexes. Reagents and conditions: a) THF, $\mathrm{NaOH}, \mathrm{RT}, 24 \mathrm{~h}, 36 \%$; b) TFA, $70^{\circ} \mathrm{C}, 1 \mathrm{~h}, 100 \%$; c) EtOH, $\mathrm{NaOH}$; d) EtOH/Water (5/5), diamine(dinitro)platinum(II), RT, $48 \mathrm{~h}, 92 \%$. 
The preparation of the dyads made of gold porphyrin/platinum complex required the porphyrin $\mathbf{8}$ as key intermediate (Scheme 2). Towards this goal, the ditertbutyl 4-(4-formylbenzyl)malonate 7 was first prepared by C-alkylation of the 4-(bromomethyl)- benzaldehyde6 in $64 \%$ yield. The tertbutyl ester was preferred over methyl or ethyl malonate owing its fast and quantitative hydrolysis in acidic conditions. Indeed, gold porphyrins are electron deficient molecules and in basic conditions they can undergo nucleophilic addition of hydroxide in meso position. ${ }^{17}$ The key porphyrin 8 was synthesized by crosscondensation of pyrrole with benzaldehyde and ditertbutyl 4-(4-formylbenzyl)malonate 7. Using Adler conditions (reflux of the reagents in propionic acid), ${ }^{18}$ the porphyrin was obtained in $12 \%$ yield, while Lindsey conditions (reaction conducted at $\mathrm{RT}$ in $\mathrm{CH}_{2} \mathrm{Cl}_{2}$ ) ${ }^{19}$ with $\mathrm{BF}_{3}-\mathrm{OEt}_{2}$ as catalyst afforded 8 in lower yield (5\%). However, Lindsey conditions with a mixture of two catalysts $\mathrm{BF}_{3}-\mathrm{OEt}_{2} / \mathrm{TFA}: 0.019 / 1$ at 0.01 $\mathrm{M}$ improved the yield of 8 to $22 \%$.

The insertion of $\mathrm{Au}(\mathrm{III})$ into the porphyrin was performed according to Sauvage methodology ${ }^{20}$ using a $\mathrm{Au}(\mathrm{l})$ based complex surrounded with weakly binding ligand (THT=tetrahydrothiophene) and can be conducted under mild reaction conditions (Scheme 2). Classical conditions, using the salt $\mathrm{KAuCl}_{4}$ in refluxing acetic acid, were too harsh and caused hydrolysis of the ester groups and partial decarboxylation. Lastly, the introduction of the platinum complex was accomplished with Dhara's methodology similarly as for the reference complexes except that the solvent was adapted to these more hydrophilic compounds (mixture of ethanol and water). The complexes were characterized by proton NMR and IR spectroscopy, elemental analysis as well as by high resolution mass spectrometry. The dyads AuP-PtNH ${ }_{3}$, AuP-PtPy and AuP-PtCyDA are soluble in ethanol, DMSO and acetone. 

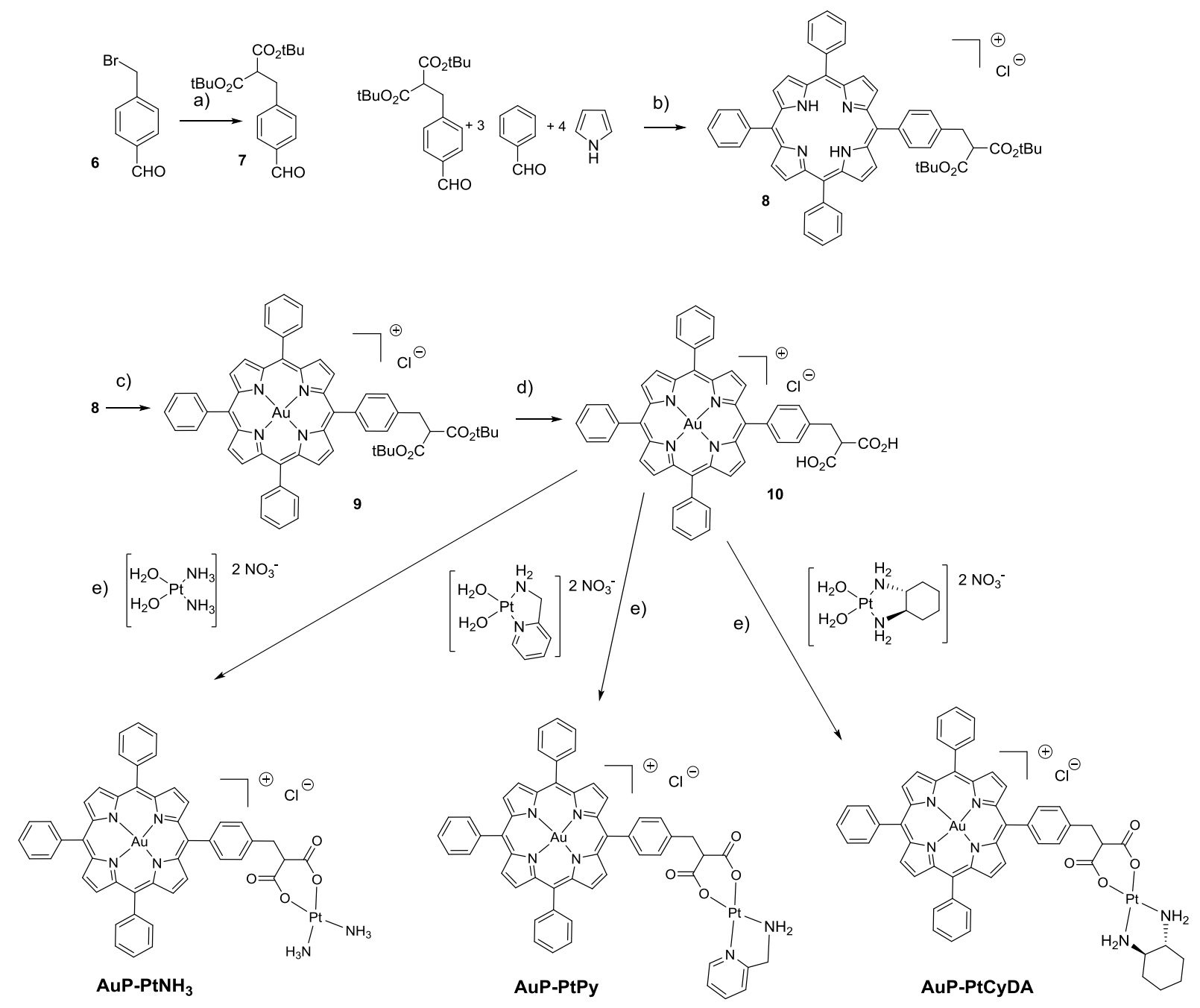

Scheme 2. Synthetic route for the preparation of the dyads gold porphyrin linked to platinum complex. Reagents and conditions: a) THF, $\mathrm{NaH}$, ditertbuthyl malonate, $1 \mathrm{~h}, 78 \%$; b) $\mathrm{CH}_{2} \mathrm{Cl}_{2}, \mathrm{BF}_{3}$. $\mathrm{Et}_{2} \mathrm{O}, \mathrm{TFA}, 2 \mathrm{~h}$, $\mathrm{DDQ}, 2 \mathrm{~h}, 22 \%$; c) $\mathrm{CHCl}_{3}, \mathrm{Au}(\mathrm{THT})_{2} \mathrm{BF}_{4}$, lutidine, reflux, 3h, $70 \%$; d)TFA, $70^{\circ} \mathrm{C}, 7 \mathrm{~h}, 94 \%$; e) ethanol/water, $\mathrm{NaOH}$, diamine(dinitro)platinum(II), RT, 48h, 90\%.

\section{UV-vis electronic absorption spectra}

The absorption spectra of the dyads gold porphyrin/platinum complex along with that of the reference AuTPP recorded in dichloromethane are shown in Figure 1 and the spectroscopic data are gathered in Table 1 . The spectra of the dyads are essentially dominated by the transitions of the gold(III)porphyrin, since the Pt complexes does not exhibit any absorption band in the visible region. The presence of the malonate on one phenyl substituent does not modify the transition on the porphyrin, since there is no $\pi$-conjugation with it. In addition, the meso aryl substituents of porphyrins are known to orient with circa $60^{\circ}$ angle preventing electronic interaction between them. ${ }^{21}$ 
Table 1.Maximum absorption wavelengths and molar extinction coefficients of the porphyrins recorded in dichloromethane at room temperature.

\begin{tabular}{|c|c|}
\hline Compounds & $\lambda_{\text {abs }} / \mathrm{nm}\left(\log \varepsilon / \mathrm{M}^{-1} \mathrm{~cm}^{-1}\right)$ \\
\hline AuP-PtNH & \\
\hline AuP-PtPy & $407(5.49) ; 522(4.18)$ \\
\hline AuP-PtCyDA & $407(5.45) ; 526(4.01) ; 529(4.03)$ \\
\hline $\mathbf{8}$ & $417(5.69) ; 507(4.12) ; 542(3.76) ;$ \\
& $584(3.64) ; 637(3.39)$ \\
\hline $\mathbf{9}$ & $407(5.60) ; 527(4.23)$ \\
\hline $\mathbf{1 0}$ & $407(5.49) ; 524(4.16)$ \\
\hline AuTPP & $409(5.44) ; 527(4.11)$ \\
\hline
\end{tabular}

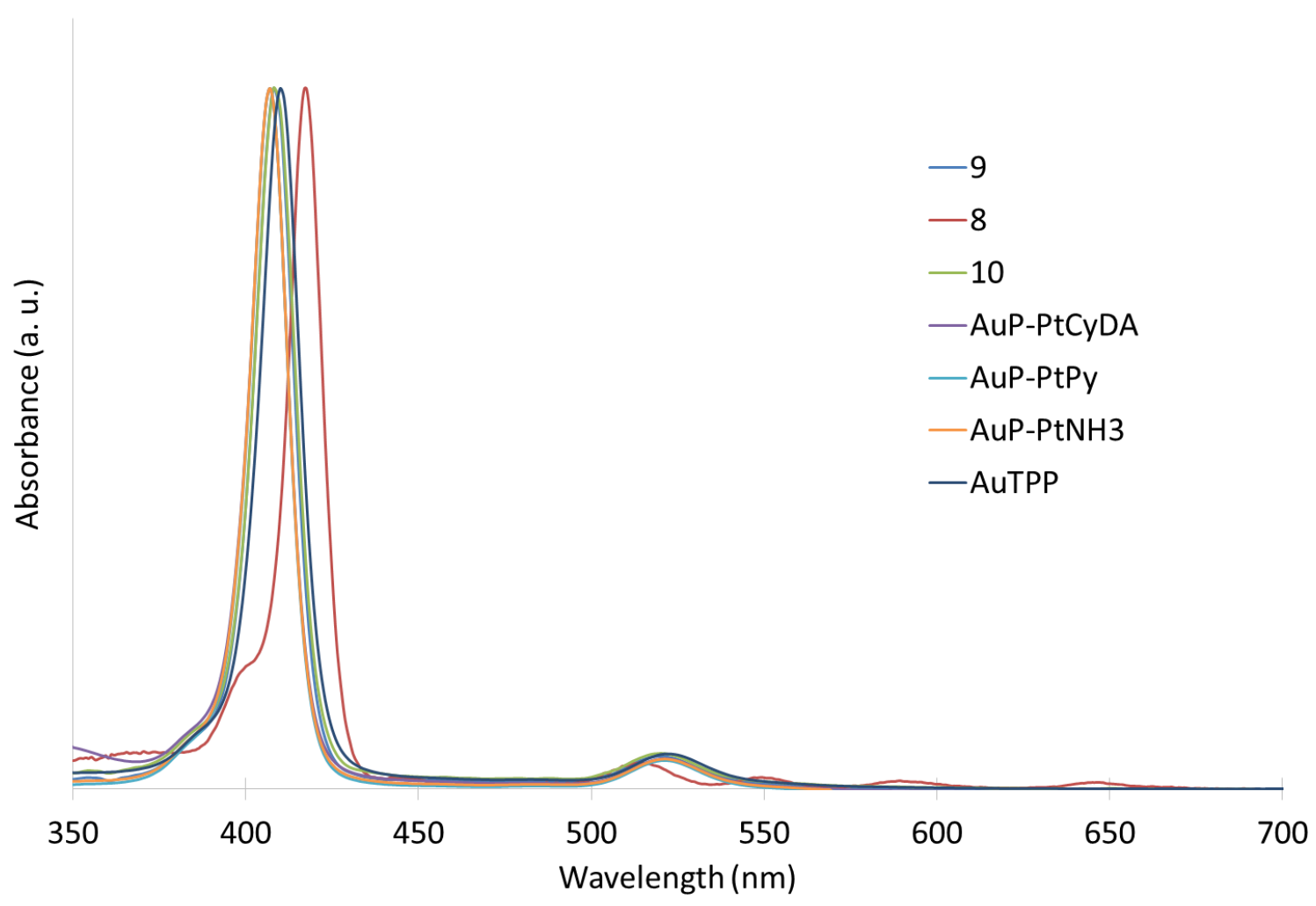

Figure 1. Normalized absorption spectra of the porphyrin derivatives recorded in dichloromethane.

Unsurprisingly, the presence of the appended platinum complex does not alter the spectrum of the gold porphyrin owing to the deconjugation induced by the methylene spacer between the porphyrin 
and the Pt complex. The absorption bands of the gold(III)-porphyrin are characterized by a hypsochromic shift of both the Soret and the Q-bands relative to those in the free base porphyrin (Figure 1). These spectral features are explained by $\mathrm{Au}^{\mathrm{III}}-\mathrm{N}$ bonding interactions, consequently leading to stabilization of the HOMO levels, and an increase in the HOMO-LUMO gap with respect to that of the free base. ${ }^{22}$

\section{Singlet oxygen measurements}

Most of the porphyrins used in PDT operate according to a type II mechanism, that is the production of singlet oxygen by energy transfer from the photosensitizer excited state to oxygen present in the biological tissues. ${ }^{2 a, b}$ The singlet oxygen quantum yield production was therefore measured to assess the potential of these gold porphyrin systems to act as sensitizers for PDT. The measurements were recorded in methanol and the production of singlet oxygen was assayed by recording the band at 1270 $\mathrm{nm}$ of singlet oxygen emission after gold porphyrin systems illumination. Unfortunately, none of the gold porphyrin and dyads prepared in this work produced detectable luminescence signal setting, thus a singlet oxygen quantum yield was below $1 \%$. This unexpected result probably stems from the short lived triplet excited state of gold(III) porphyrins $(\tau \approx 1.5 \mathrm{~ns})$, which decay to ground state before the energy transfer to surrounding oxygen could take place. ${ }^{12,23}$

\section{Biological activity}

In order to determine the therapeutic potential of these new compounds, we have first studied the cytotoxicity induced in human breast cancer cells (MCF-7) and in healthy human fibroblasts (FS-68). The cells were incubated in darkness during $72 \mathrm{~h}$ with increasing concentrations of each compound (from 0.01 to $100 \mu \mathrm{M}$ ). The concentrations of the drugs which led to $50 \%$ cell mortality $\left({ }^{2} C_{50}\right)$ were determined. As shown in Figure 2, obtained cytotoxicity data in both cell lines showed the classical sigmoidal dose-response curves when plotted as a logarithmic function of concentration $(\mu \mathrm{M})$. Figure $2 a, b$ illustrates the dose dependent cytotoxic effect of the reference platinum complexes $\mathbf{P t}-\mathbf{N H}_{3}, \mathbf{P t}$ Py and PtCyDA which are in the range of those reported with similar compounds and the ranking is consistent with previous studies ${ }^{5 f, 24}$ : Pt- $\mathbf{N H}_{3}<\mathrm{Pt}-\mathrm{Py}<\mathrm{PtCyDA}$. Overall, the Pt complex with the ligand CyDA is the most cytotoxic of the series with a lowerl $C_{50}$ value than Cisplatin $\left({ }^{2} C_{50}(\right.$ Cisplatin $\left.) \approx 5 \mu \mathrm{M}\right){ }^{25}$ Importantly, the cell death is very low in healthy fibroblasts, $\mathrm{IC}_{50}$ is too high to be calculate precisely $(\geq 100 \mu \mathrm{M})$ (Figure $2 \mathrm{c})$. This result highlights the targeting of cancer cells by these compounds. 

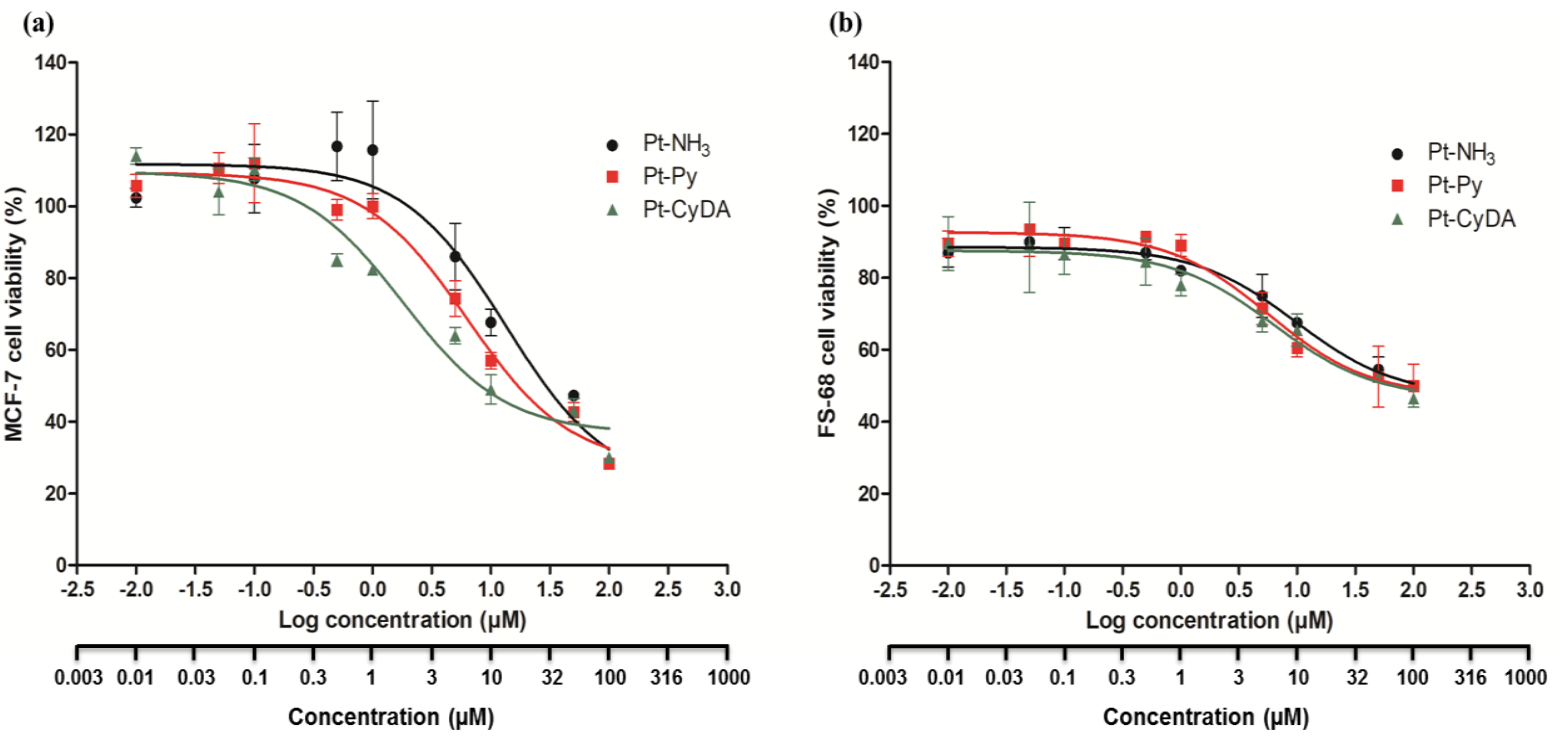

(c)

\begin{tabular}{|l|l|l|}
\hline Compounds & $\begin{array}{l}\text { IC50 }(\mu \mathrm{M}) \\
\text { MCF-7 }\end{array}$ & $\begin{array}{l}\text { IC50 }(\mu \mathrm{M}) \\
\text { FS-68 }\end{array}$ \\
\hline Pt-NH 3 & 13.35 & $\geq 100$ \\
\hline Pt-Py & 6.33 & $\geq 100$ \\
\hline Pt-CyDA & 1.81 & $\geq 100$ \\
\hline
\end{tabular}

Figure 2.Cytotoxic study of Pt-NH $\mathrm{NH}_{3}$, Pt-Py and PtCyDA. (a)Human breast cancer cells (MCF-7) and (b) healthy fibroblasts cells (FS-68) were incubated $72 \mathrm{~h}$ with increasing concentrations of $\mathbf{P t}-\mathrm{NH}_{3}, \mathbf{P t}-\mathbf{P y}$ and PtCyDA and maintained in darkness. Values are means \pm standard deviation of 3 experiments. (c) $\mathrm{IC}_{50}$ values are reported for each cell line.

Then, the cytotoxic activity of gold porphyrins AuTPP, $\mathbf{9}$ and $\mathbf{1 0}$ was investigated in both human breast cancer cells (Figure 3a) and in healthy fibroblasts cells (Figure 3b). The results first show that overall, the gold porphyrins are more potent than the reference platinum complexes. Although the difference of cytotoxicity in cancer cells between Pt-CyDA and $\mathbf{1 0}$ is small, but on healthy fibroblasts this difference become very high; close to 100 fold (Table 3c). In addition, the introduction of the malonate substituent on the porphyrin decreases its cytotoxic activity, since the simple AuTPP has the lowest $\mathrm{IC}_{50}$. This result is consistent with the report of Che and co-workers, showing that any substituent pattern on AuTPP results in a weakening of its cytotoxicity. ${ }^{8 a}$ Important features for the anticancer activity of gold(III) porphyrins are the size of the macrocycle, which must fit in the cavity of the target receptor (certainly heat shock protein) ${ }^{10}$ and the lipophilicity of the porphyrin because its biological properties might be related to the fact it is a planar aromatic organic cation. ${ }^{26}$ Thus, complex 9 with bulky hydrophobic malonate substituent displayed the least activity, which might be attributed to traffic entrance into cells. A long floppy alkyl chain might have been more favorable to tether the platinum complex and to maintain the cytotoxic activity of gold(III) porphyrin. Finally, we note that for 
gold porphyrins AuTPP and 10, the cytotoxicity is lower on healthy cells than cancerous ones, a significant advantage to decrease side effects during the treatment.

(a)

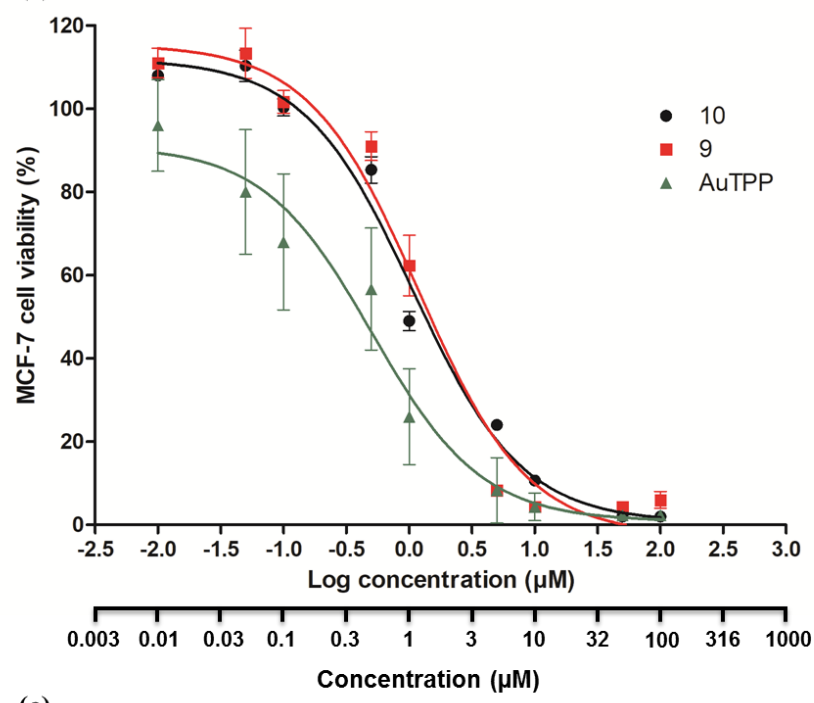

(c) (b)

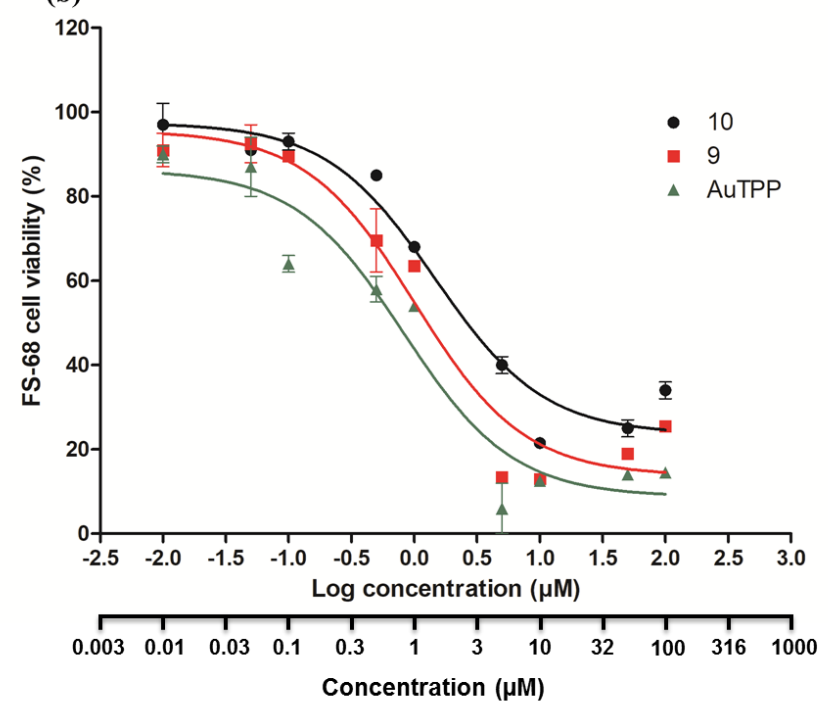

Figure 3. Cytotoxic study of AuTPP, 9 and 10. (a)Human breast cancer cells (MCF-7) and (b) healthy fibroblasts cells (FS-68) were incubated $72 \mathrm{~h}$ with increasing concentrations of AuTPP, 9 and 10and maintained in darkness. Values are means \pm standard deviation of 3 experiments. (c) $I C_{50}$ values are reported for each cell line.

Then, the photodynamic therapy efficiency of the gold porphyrins was studied in order to determine the possibility of a dual therapy that could increase, after light excitation, the cell death already due to the cytotoxicity of the compound (Figure 4). Cancer cells were thus incubated for $24 \mathrm{~h}$ with AuTPP, 9 and 10at a concentration of $0.5 \mu \mathrm{M}$ and then irradiated or not with the mercury lamp of a fluorescent microscope $\left(20 \mathrm{~min}, \lambda_{\text {exc }}=390-420 \mathrm{~nm}, 39 \mathrm{J.cm}^{-2}\right)$. The cell death quantification performed 2 days after illumination demonstrates a decrease in living cells treated and submitted to photoexcitation. In fact, light excitation induces a supplementary cell death in addition to their intrinsic cytotoxicity and the most significant effect was obtained by the photoexcitation of AuTPP for which the illumination induced $18 \%$ of cell death to add to the $70 \%$ of cell death obtained without light. However, the additional cell mortality generated upon light excitation remains modest, indicating that gold porphyrins have weak, but not null, cytotoxic as compared for other sensitizers, such as free base porphyrins. ${ }^{13 a, 27}$ As mentioned above, the low phototoxicity of gold porphyrins is certainly explained 
by the very weak singlet oxygen generation quantum yield of these compounds, since porphyrins usually display higher ones. ${ }^{27 a, 28}$

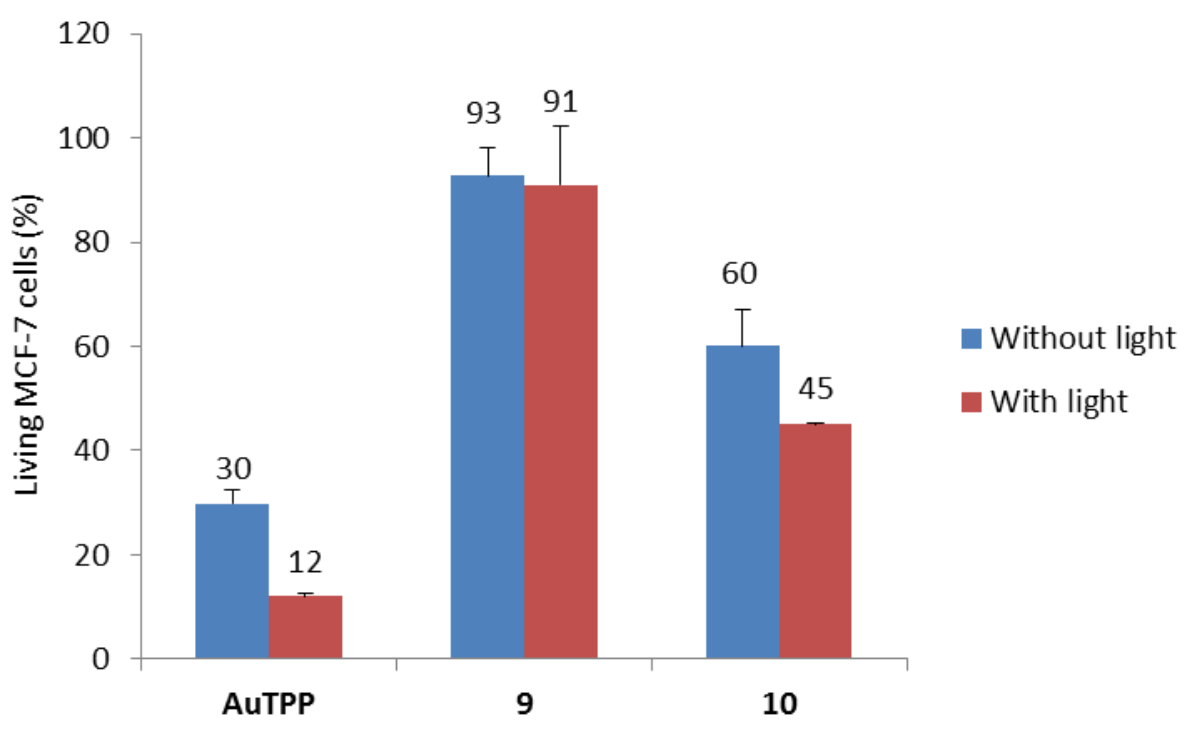

Figure 4.Phototoxicity of AuTPP, 9 and 10incubated at $0.5 \mu \mathrm{M}$ with MCF-7 cells during $24 \mathrm{~h}$ and irradiated $20 \mathrm{~min}$ at $\lambda_{\mathrm{exc}}=390-420 \mathrm{~nm}\left(39 \mathrm{~J}_{\mathrm{cm}} \mathrm{cm}^{-2}\right)$.Values are means \pm standard deviation of 3 experiments.

Finally, the toxicity (Figure 5) and phototoxicity (Figure 6) of the three dyads were tested. On cancer and healthy cells (Figure $5 \mathrm{a}, \mathrm{b}, \mathrm{c}$ ), all of them display $\mathrm{IC}_{50}$ values at the micromolar level, which are lower than those of the reference platinum complexes, but remain in the same range, let alone a bit better, as that of the reference gold porphyrin 10. Again, the most active dyad is AuP-PtCyDA, where the Pt is liganded with cyclohexane diamine. The cytotoxicity effect of the bimetal porphyrin conjugates AuP$\mathrm{PtNH}_{3}$, AuP-PtPy and AuP-PtCyDA was increased by 5.6, 4.7 and 2 fold enhancement, respectively, compared to their corresponding Pt-complexes. These results would suggest that porphyrins granted the transport of the complex inside the cancer cell for more favorable cytotoxicity. As expected, the CyDA complex showed the highest effect. 

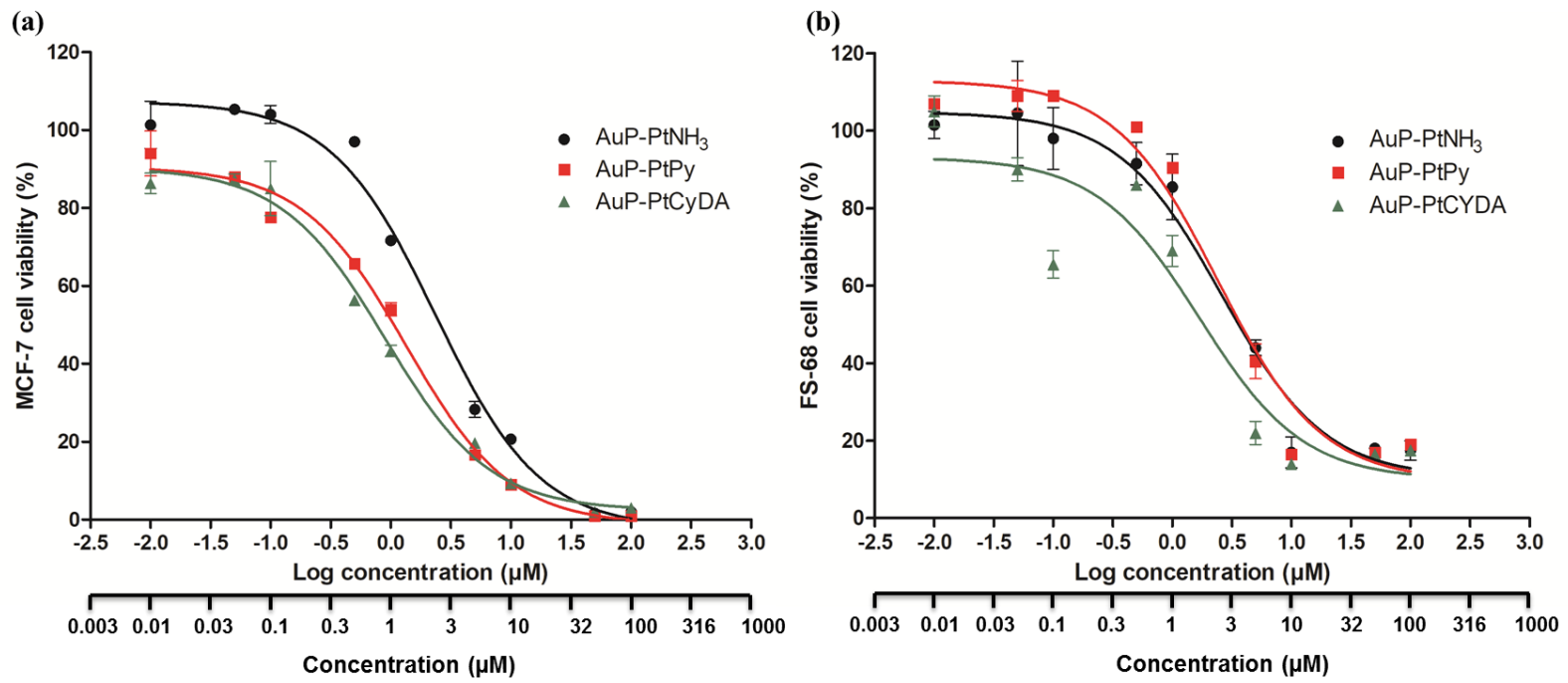

(c)

\begin{tabular}{|l|l|l|}
\hline Compounds & $\begin{array}{l}\text { IC50 }(\mu \mathrm{M}) \\
\text { MCF-7 }\end{array}$ & $\begin{array}{l}\text { IC50 }(\mu \mathrm{M}) \\
\text { FS-68 }\end{array}$ \\
\hline AuP-PtNH & 2.36 & 2.23 \\
\hline AuP-PtPy & 1.34 & 2.41 \\
\hline AuP-PtCyDA & 0.90 & 1.70 \\
\hline
\end{tabular}

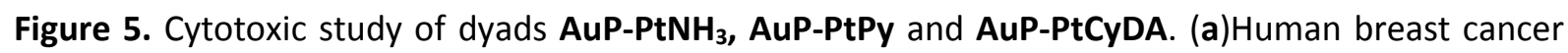
cells (MCF-7) and (b) healthy fibroblasts cells (FS-68) were incubated $72 \mathrm{~h}$ with increasing concentrations of dyads AuP-PtNH ${ }_{3}$, AuP-PtPy and AuP-PtCyDAand maintained in darkness. Values are means \pm standard deviation of 3 experiments. (c) IC $C_{50}$ values are reported for each cell line.

Similarly as for the reference gold porphyrins (AuTPP, 9 and 10), light excitation increases cell mortality, but to a low extent (Figure 6). Similarly as for the reference gold porphyrins (AuTPP, 9 and 10), light excitation increases cell mortality, but to a low extent (Figure 6). In addition, AuP-PtCyDA does not exhibit PDT efficiency in these conditions."

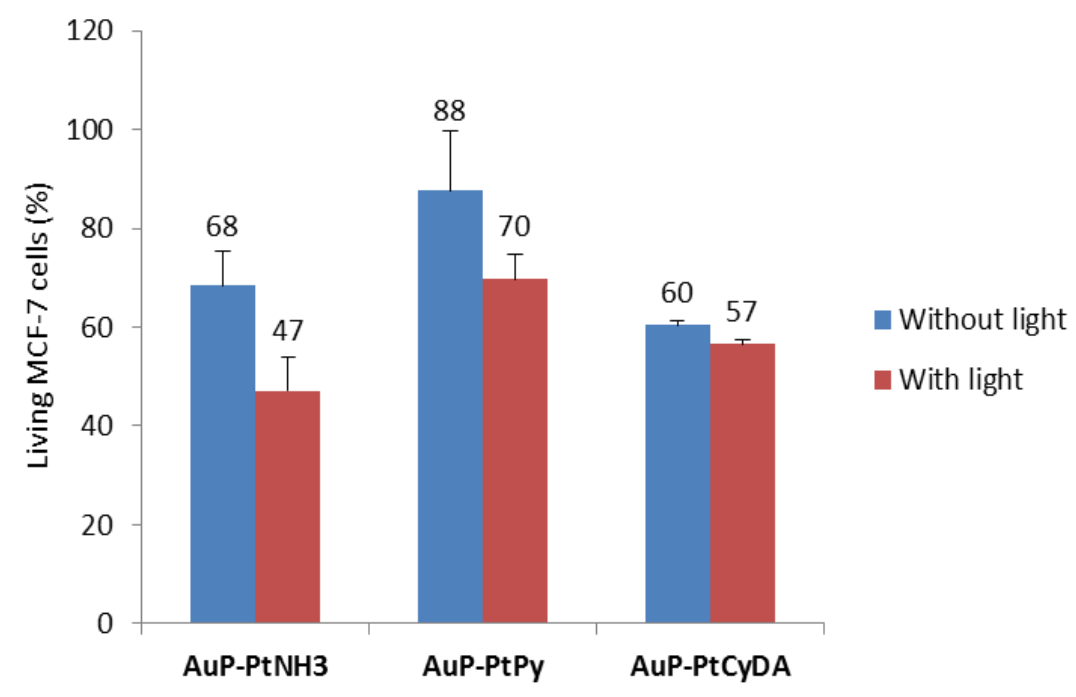


Figure 6.Phototoxicityofdyads AuP-PtNH ${ }_{3}$, AuP-PtPyandAuP-PtCyDAincubated at $0.5 \mu \mathrm{M}$ with MCF-7 cells during $24 \mathrm{~h}$ and irradiated $20 \mathrm{~min}$ at $\lambda_{\mathrm{exc}}=390-420 \mathrm{~nm}\left(39 \mathrm{~J} . \mathrm{cm}^{-2}\right)$. Values are means $\pm \mathrm{standard}$ deviation of 3 experiments.

To confirm that the phototoxicity induced by photoexcitation was due to PDT effect, we studied the reactive oxygen species (ROS) production in MCF-7 cells human cells treated with the compounds PtCyDA (as negative control), AuTPP and AuP-PtPy with or without laser irradiation. Cells were first incubated with $\mathrm{DCFH}_{2}$-DA $\left(2^{\prime}, 7^{\prime}\right.$-dichlorodihydrofluorescein diacetate), which is a non-fluorescent molecule. In the presence of ROS produced within the cell, this molecule is oxidized into the fluorescent 2',7'-dichlorofluorescein (DCF) and its green luminescence can be detected at $\lambda=450 \mathrm{~nm}$ using fluorescent microscope. The results, reported in Figure 7, showed that the light induced an increase in green fluorescence inside the cells incubated with AuTPP and AuP-PtPy traducing thus a ROS production and suggesting a cell death induced by PDT. The singlet oxygen measurements have shown that all these porphyrin derivatives are poor oxygen photosensitizers, therefore it is likely that the ROS production is induced by generating cytotoxic radicals via electron transfer from excited AuP ${ }^{+}$ to surrounding organic molecules such as glutathione, a ubiquitous antioxidant in cells, upon reductive quenching of AuP ${ }^{+}$excited state, which is a strong oxidant. ${ }^{12}$ Accordingly, PDT effect can arise by a type I mechanism, which passes via the formation of oxidized species, inducing thus an oxidative stress by oxidizing GSH to glutathione disulfide. Photosensitizers operating upon a type I mechanism is particularly interesting in hypoxic environments found in many solid tumours.
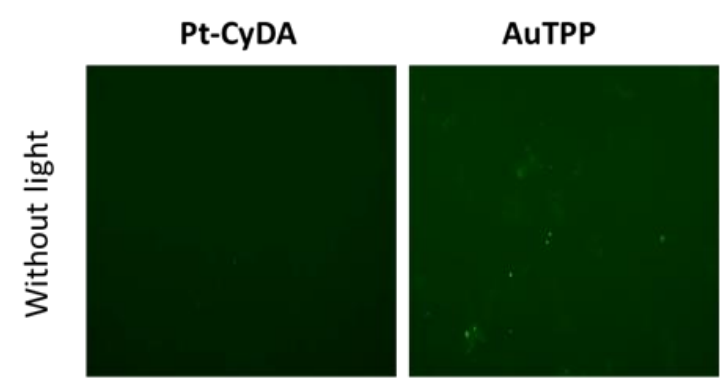

\section{AuP-PtCyDA}
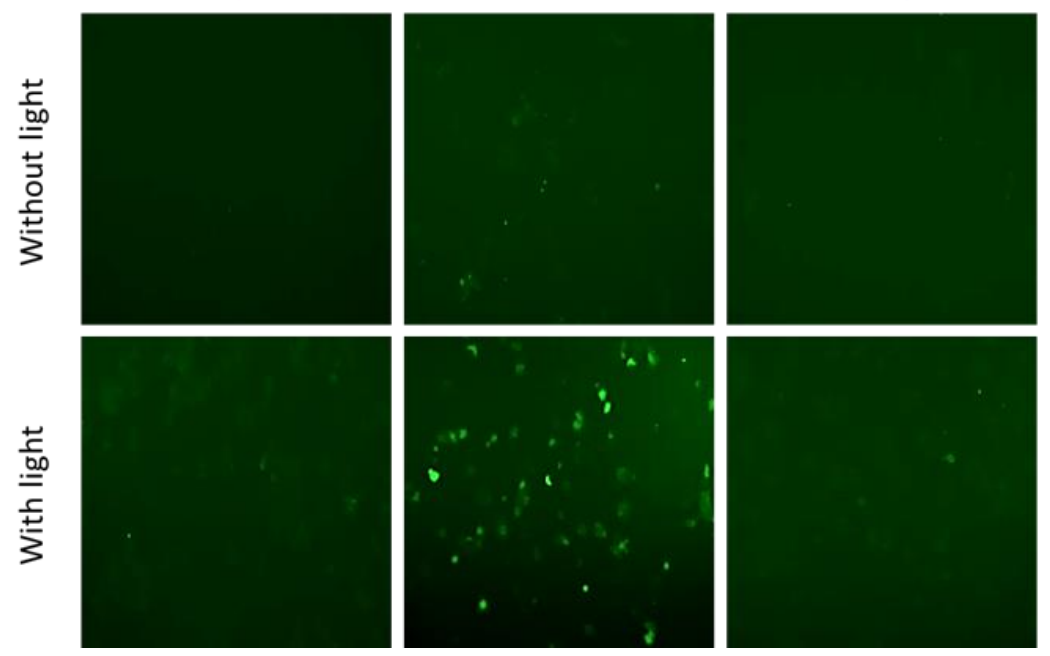

Figure 7.ROS production in MCF-7 cells incubated with Pt-CyDA, AuP-PtCyDA and AuTPP at $0.5 \mu \mathrm{M}$ during $24 \mathrm{~h}$ and irradiated $20 \mathrm{~min}$ at $\lambda_{\text {exc }}=390-420 \mathrm{~nm}\left(39 \mathrm{~J} . \mathrm{cm}^{-2}\right)$. Green luminescence shows the generation of ROS detected at $\lambda=450 \mathrm{~nm}$. 
Finally, we decided to study the PDT effect in healthy fibroblasts in the same conditions as those used for cancer cells (Figure 8). For this, FS-68 cells were incubated $24 \mathrm{~h}$ with $0.5 \mu \mathrm{M}$ of compounds and were submitted to light excitation at $\lambda_{\mathrm{exc}}=390-420 \mathrm{~nm}, 39 \mathrm{~J} . \mathrm{cm}^{-2}$. The quantification of living cells 2 days after the PDT experiment showed a total absence of phototoxic effect. This result highlights the specific effect of PDT on cancer cells and suggests that there could be no photoxicity on healthy cells around the tumor.

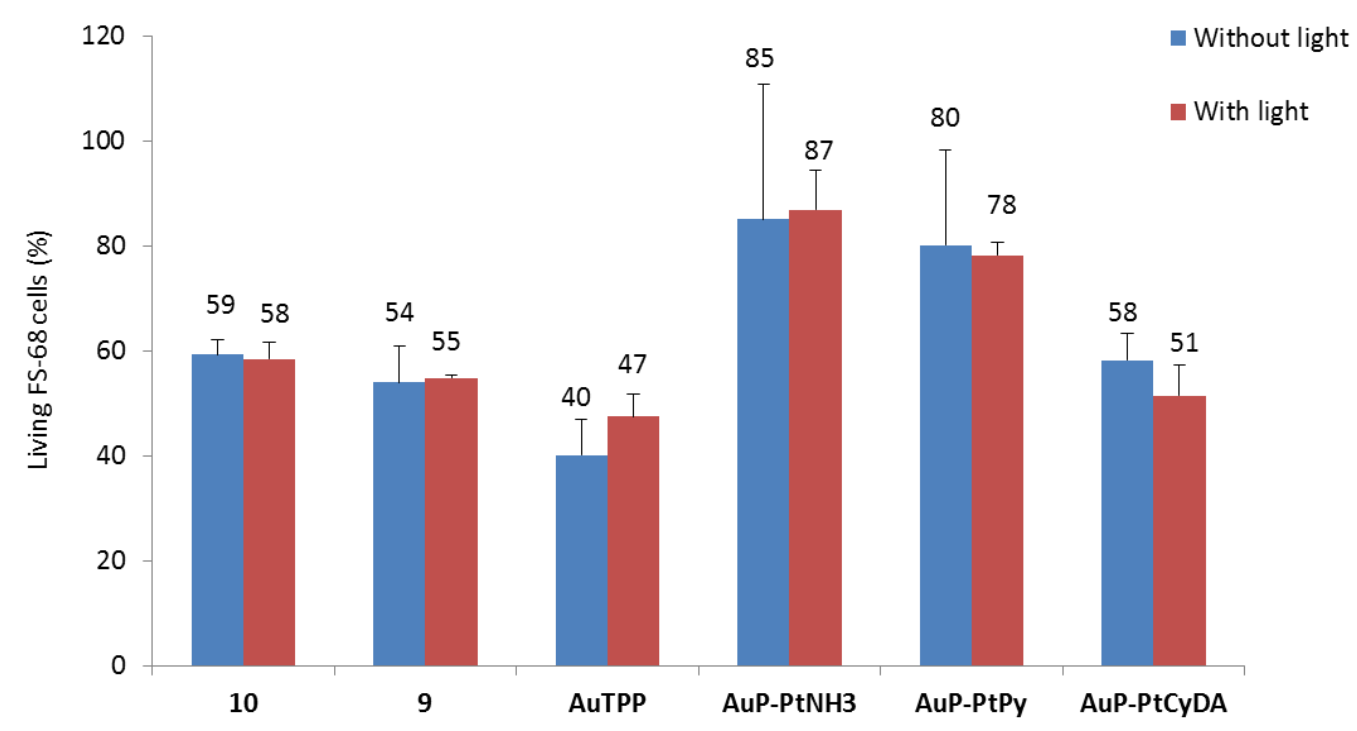

Figure 8. Phototoxicity of gold porphyrins 10, 9, AuTPP and dyads AuP-PtNH H $_{3}$ AuP-PtPy,AuPPtCyDAincubated at $0.5 \mu \mathrm{M}$ with healthy fibroblasts (FS-68) during $24 \mathrm{~h}$ and irradiated $20 \mathrm{~min}$ at $\lambda_{\text {exc }}=$ $390-420 \mathrm{~nm}\left(39 \mathrm{~J} . \mathrm{cm}^{-2}\right)$. Values are means \pm standard deviation of 3 experiments.

\section{Conclusion}

For the first time, we report three new dyads consisting of two appended cytotoxic moieties such as a gold(III) porphyrin and a platinum complex and their biological properties towards cancer cells were investigated in the dark (chemostatic effect) and upon light excitation (PDT effect) and compared to their corresponding individual platinum(II) complexes. To evaluate the decrease in side effects that could occur with such compounds, the effect on healthy cells was also studied. The main results of this work are: i) the diamine ligand around the Pt centre has a high impact on the cytotoxicity of the resulting complex and cyclohexane diamine is the best ligand; ii) the gold porphyrins are poor singlet 
oxygen photosensitizers and thereby exhibit low phototoxicity with the present systems, but improvement can be obtained with modification of the porphyrin core, such as fluorination. The presence of fluorine atoms on meso phenyl substituents could enhance both the oxidizing power ${ }^{29}$ and the lifetime of the triplet excited state. Indeed, it is postulated that gold porphyrins display ligand to metal charge transfer transitions, which are responsible of the fast decay of the triplet excited state. ${ }^{23}$ However, the phototoxicity is not null and most probably result by a type I mechanism; iii) the introduction of a malonate group of one phenyl substituent of AuTPPs lightly decreases cyto- and photoxicity the gold porphyrin; iv) the dyad AuP-PtCyDA displays interesting cytotoxic activity towards cancer cells, for which the mechanism of action would be interesting to be investigated.The enhanced cytotoxicity indicates that porphyrins allow the delivery of the complex into cancer cells. The complex might have dual biological functioning between $\mathrm{Au}(\mathrm{III})$ and $\mathrm{Pt}(\mathrm{II})$ arms. The former as reported would interact with mitochondria and the latter would target DNA; both mechanisms cause cancer cell death.

Importantly, all compounds present a close or clearly higher cytotoxic activity in cancer cells than healthy cells and the PDT effect, even slight, induced around 15 or $20 \%$ more cancer cell death for AuTPP, AuP-PtNH ${ }_{3}$ and AuP-PtPy in conditions totally harmless for healthy cells ( $0 \%$ cell death).

Further biological analysis would clarify the anticancer activity if it is based on specific metal or both. Additional analysis of the intracellular metal contents such as ICP-analysis to monitor the uptake of the whole stable bimetal conjugate by cancer cells would clarify the delivery mechanism. On the other hand, the incorporate mode of action exhibited by the two metals may be even amplified using an alternative photosensitizer. These studies are in due course in our laboratory.

\section{Acknowledgments}

We thank Campus France (Eiffel grant), Pays de la Loire (LUMOMAT project), CNRS-L and the Lebanese University for the financial support of this project.

\section{Experimental part}

\section{Synthesis of the compounds}

\section{Generalities}


${ }^{1} \mathrm{H}$ and ${ }^{13} \mathrm{C}$ NMR spectra were recorded on an AVANCE 300 Ultrashield BRUKER and AVANCE 400 BRUKER. Chemical shifts for ${ }^{1} \mathrm{H}$ and ${ }^{13} \mathrm{C}$ NMR spectra are referenced relative to residual proton in the deuterated solvent $\left(\mathrm{CDCl}_{3} \delta=7.26 \mathrm{ppm}\right.$ for ${ }^{1} \mathrm{H}, \mathrm{DMSO}-\mathrm{d}^{8} \delta=2.50 \mathrm{ppm}$ for $\left.{ }^{1} \mathrm{H}\right)$ or to an internal reference (TMS, $\delta=0$ ppm for both ${ }^{1} \mathrm{H}$ ). NMR spectra were recorded at room temperature, chemical shifts are written in ppm and coupling constants in $\mathrm{Hz}$. High-resolution mass (HR-MS) spectra were obtained by electrospray ionization coupled with high resolution ion trap orbitrap (LTQ-Orbitrap, ThermoFisher Scientific), working in ion-positive or ion-negative mode.

Chemicals were purchased from Sigma-Aldrich or Alfa Aesar and used as received. Thin-layer chromatography (TLC) was performed on silica sheets precoated with Merck 5735 Kieselgel $60 \mathrm{~F}_{254}$. Column chromatography was carried out with Merck 5735 Kieselgel 60F (0.040-0.063 mm mesh).Bromo ditertbutyl malonate 2, 4-(bromomethyl)-benzaldehyde6and platinum precursors $\mathrm{Pt}\left(\mathrm{OH}_{2}\right)_{2}\left(\mathrm{NH}_{3}\right)_{2}-\left(\mathrm{NO}_{3}\right)_{2}$, $\mathrm{Pt}\left(\mathrm{OH}_{2}\right)_{2}(\mathrm{Py})-\left(\mathrm{NO}_{3}\right)_{2}$ and $\mathrm{Pt}\left(\mathrm{OH}_{2}\right)_{2}(\mathrm{CyDA})-\left(\mathrm{NO}_{3}\right)_{2}$ were synthesized according to literature.

Ditertbutylmalonate p-cresol (3). A total of $1 \mathrm{~g}(9.24 \mathrm{mmol})$ of $\mathrm{p}$-cresol 1 and $2.7 \mathrm{~g}(9.24 \mathrm{mmol})$ of bromoditertbutyl malonate2were dissolved under argon in $20 \mathrm{ml}$ of distilled THF. $0.36 \mathrm{~g}$ ( $9 \mathrm{mmol}$ ) of pulverized $\mathrm{NaOH}$ was added, and the mixture was stirred for $24 \mathrm{~h}$ at room temperature. The organic solution was diluted with water and extracted with dichloromethane. The combined organic phases were washed with water and dried over $\mathrm{Na}_{2} \mathrm{SO}_{4}$. The solvent was evaporated and the crude product was purified by column chromatography $\left(\mathrm{SiO}_{2} ; \mathrm{CH}_{2} \mathrm{Cl}_{2} /\right.$ petroleum ether 5/5). Yield: $(1.08 \mathrm{~g}, 36 \%)$.NMR $\left({ }^{1} \mathrm{H}, \mathrm{CDCl}_{3}, 300 \mathrm{MHz}\right) \delta(\mathrm{ppm}): 7.07-7.04(\mathrm{~d}, 2 \mathrm{H}, J=8.63 \mathrm{~Hz}), 6.86-6.84(\mathrm{~d}, 2 \mathrm{H}, J=8.63 \mathrm{~Hz}), 4.92(\mathrm{~s}, 1 \mathrm{H})$, $2.26(\mathrm{~s}, 3 \mathrm{H}), 1.48(\mathrm{~s}, 18 \mathrm{H})$. HRMS (ES+) [M+] m/z 345.1672 found, 345.1678 calc.

Compound (4). $206 \mathrm{mg}(0.63 \mathrm{mmol})$ of 3 was dissolved in $1 \mathrm{ml} \mathrm{TFA}$ and heated at $70^{\circ} \mathrm{C}$ for one hour. The solvent was evaporated and the product was dried under vacuum. Yield: (134 mg, 100\%). IR (ATR): $1706 \mathrm{~cm}^{-1}$ (C=O).NMR ( $\left.{ }^{1} \mathrm{H}, \mathrm{CDCl}_{3}, 300 \mathrm{MHz}\right) \delta(\mathrm{ppm}): 7.10-7.08(\mathrm{~d}, 2 \mathrm{H}, J=8.63 \mathrm{~Hz}), 6.82-6.80(\mathrm{~d}, 2 \mathrm{H}, J$ $=8.61 \mathrm{~Hz}), 5.25(\mathrm{~s}, 1 \mathrm{H}), 2.22(\mathrm{~s}, 3 \mathrm{H})$. HRMS (ES+) [M+] m/z 209.0454 found, 209.0450 calc.

General procedure 1 (GP 1). Compound 4 was dissolved in water and the carboxylic acid functions were activated into sodium carboxylates, using 2 eq of $\mathrm{NaOH} .1 .2$ eq of the respective diammine(dinitro)platinum(II) complex was dissolved in ethanol and added.The solution was stirred for $48 \mathrm{~h}$ at room temperature. The precipitated complexes Pt-Py, Pt-NH $\mathbf{N H}_{3}, \mathbf{P t}-\mathbf{C y D A}$ were filtered and dried. 


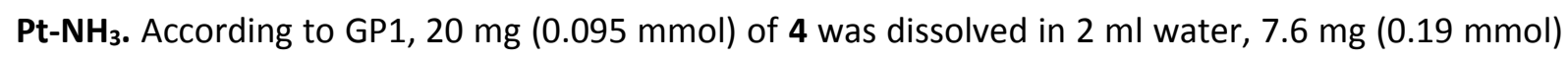
of $\mathrm{NaOH}$ was added, combined with $40 \mathrm{mg}(0.11 \mathrm{mmol})$ of diamine(dinitro)platinum(II) dissolved in 2 $\mathrm{ml} \mathrm{EtOH}$, and stirred for $48 \mathrm{~h}$. The precipitated complexPt-NH $\mathrm{N}_{3}$ was filtered, washed with water and dried. Yield (38 mg, 92\%).IR (ATR): $1669 \mathrm{~cm}^{-1}(\mathrm{C}=0) . \mathrm{NMR}\left({ }^{1} \mathrm{H}, \mathrm{DMSO}, 300 \mathrm{MHz}\right) \delta(\mathrm{ppm}): 7.03$ (br, 2H), $6.66(\mathrm{br}, 2 \mathrm{H}), 5.70(\mathrm{~s}, 1 \mathrm{H}), 4.29(\mathrm{br}, 6 \mathrm{H}), 2.20(\mathrm{~s}, 3 \mathrm{H})$. HRMS (ES+) [M+] m/z 459.0412 found, 459.0427 calc. Elem. Anal. Exp C, 27.68; H, 3.20; N, 6.19 .calc C, 27.47; H, 3.23; N, 6.41.

Pt-CyDA. According to GP1, $40 \mathrm{mg}(0.19 \mathrm{mmol})$ of 4 was dissolved in $3 \mathrm{ml}$ water, $15 \mathrm{mg}(0.38 \mathrm{mmol})$ of $\mathrm{NaOH}$ was added, combined with $90 \mathrm{mg}(0.2 \mathrm{mmol})$ of diamine(dinitro)platinum(II) dissolved in $3 \mathrm{ml}$ $\mathrm{EtOH}$, and stirred for $48 \mathrm{~h}$. The precipitated complex Pt-CyDA was filtered, washed with water and dried. Yield (90 mg, 92\%).IR (ATR): $\mathrm{cm}^{-1}$ (C=O).NMR ( ${ }^{1} \mathrm{H}$, DMSO, $\left.300 \mathrm{MHz}\right) \delta(\mathrm{ppm}): 7.06-7.03(\mathrm{~d}, 2 \mathrm{H}, J$ $=8.53 \mathrm{~Hz}), 6.68-6.65(\mathrm{~d}, 2 \mathrm{H}, J=8.9 \mathrm{~Hz}), 6.16-6.03(\mathrm{dd}, 2 \mathrm{H}, J=9.9,30.91 \mathrm{~Hz}), 5.66(\mathrm{~s}, 1 \mathrm{H}), 5.45-5.33$ $(\mathrm{dt}, 2 \mathrm{H}, J=37.28,8.96 \mathrm{~Hz}), 2.21(\mathrm{~s}, 3 \mathrm{H}), 2.09(\mathrm{br}, 2 \mathrm{H}), 1.84-1.80(\mathrm{~d}, 2 \mathrm{H}, J=12.95 \mathrm{~Hz}), 1.46-1.44(\mathrm{~d}, 2 \mathrm{H}, J$ $=8.86 \mathrm{~Hz}), 1.22(\mathrm{br}, 2 \mathrm{H}), 1.04-0.97(\mathrm{t}, 2 \mathrm{H}, J=10.22 \mathrm{~Hz})$. HRMS (ES+) [M+] m/z 539.1061 found, 539.1053 calc.

Pt-Py. According to GP1, $40 \mathrm{mg}$ (0.19 mmol) of 4 was dissolved in $3 \mathrm{ml}$ water, $15 \mathrm{mg}$ (0.38 mmol) of $\mathrm{NaOH}$ was added, combined with $89 \mathrm{mg}(0.2 \mathrm{mmol})$ of diamine(dinitro)platinum(II) dissolved in $3 \mathrm{ml}$ $\mathrm{EtOH}$, and stirred for $48 \mathrm{~h}$. The precipitated complex Pt-Py was filtered, washed with water and dried. Yield (89 mg, 92\%).IR (ATR): 1681, $1649 \mathrm{~cm}^{-1}$ (C=O).NMR ( $\left.{ }^{1} \mathrm{H}, \mathrm{DMSO}, 300 \mathrm{MHz}\right) \delta$ (ppm): 8.44-8.42 (d, $1 \mathrm{H}, J=5.97 \mathrm{~Hz}), 8.18-8.12(\mathrm{td}, 1 \mathrm{H}, J=7.73,1.58 \mathrm{~Hz}), 7.66-7.63(\mathrm{~d}, 1 \mathrm{H}, J=7.8 \mathrm{~Hz}), 7.54-7.50(\mathrm{t}, 1 \mathrm{H}, J=$ $6.96 \mathrm{~Hz}), 7.05-7.02(\mathrm{~d}, 2 \mathrm{H}, J=8.36 \mathrm{~Hz}), 6.71-6.68(\mathrm{~d}, 2 \mathrm{H}, J=8.9 \mathrm{~Hz}), 6.64-6.62(\mathrm{~d}, 1 \mathrm{H}, J=5.57 \mathrm{~Hz}), 5.70$ $(\mathrm{s}, 1 \mathrm{H}), 4.15-4.14(\mathrm{br}, 2 \mathrm{H}), 2.21(\mathrm{~s}, 3 \mathrm{H})$. HRMS (ES+) [M+] m/z 511.0761 found, 511.0764 calc.

Porphyrin (8). $\mathrm{BF}_{3} . \mathrm{Et}_{2} \mathrm{O} 16 \mu \mathrm{l}\left(1.2 \times 10^{-2} \mathrm{mmol}\right)$ and $0.5 \mathrm{ml}(6.46 \mathrm{mmol})$ of trifluoroacetic acid (TFA) were added to a solution of $0.55 \mathrm{ml}(5.38 \mathrm{mmol})$ of benzaldehyde, $600 \mathrm{mg}(1.79 \mathrm{mmol})$ of 7 , and 0.35 $\mathrm{ml}(5 \mathrm{mmol})$ of freshly distilled pyrrole in $1 \mathrm{I}$ of $\mathrm{CH}_{2} \mathrm{Cl}_{2}$. The mixture was kept at room temperature for $2 \mathrm{~h} .1 .2 \mathrm{~g}(5.2 \mathrm{mmol})$ of DDQ was added when the aldehydes were completely reacted, and the mixture was kept at room temperature for an additional $2 \mathrm{~h}$. The solvent was evaporated and the crude product was purified by column chromatography $\left(\mathrm{SiO}_{2} ; \mathrm{CH}_{2} \mathrm{Cl}_{2} /\right.$ hexane 6/4) to remove tetraphenylporphyrin. The monosubtituted porphyrin was then eluted with $\mathrm{CH}_{2} \mathrm{Cl}_{2}$ in form of a thick, purple band. Yield: (331 $\mathrm{mg}, 22 \%)$. UV-Vis $\left(\mathrm{CH}_{2} \mathrm{Cl}_{2}, \mathrm{~nm}\right) \lambda_{\max }(\mathrm{nm}): 418\left(\varepsilon 4.2 \times 10^{5} \mathrm{~mol}^{-1} . \mathrm{L} . \mathrm{cm}^{-1}\right), 522\left(1.1 \times 10^{4}\right), 557\left(4.1 \times 10^{3}\right)$, $655\left(2.3 \times 10^{3}\right)$. NMR $\left({ }^{1} \mathrm{H}, \mathrm{CDCl}_{3}, 300 \mathrm{MHZ}\right) \delta(\mathrm{ppm}): 8.41-8.80(\mathrm{~m}, 8 \mathrm{H}), 8.23-8.20(\mathrm{dd}, 2 \mathrm{H}, J=7.08,7.67$ $\mathrm{Hz}), 8.14-8.11(\mathrm{~d}, 2 \mathrm{H}, J=8.02 \mathrm{~Hz}), 7.76-7.74(\mathrm{~m}, 9 \mathrm{H}), 7.61-7.58(\mathrm{~d}, 2 \mathrm{H}, J=8.15 \mathrm{~Hz}), 3.83-3.77(\mathrm{t}, 1 \mathrm{H}, J=$ 
$8.41 \mathrm{~Hz}$ ), 3.49-3.46 (d, $2 \mathrm{H}, J=7.94 \mathrm{~Hz}), 1.55(\mathrm{~s}, 18 \mathrm{H}) . \mathrm{HRMS}(\mathrm{ES}+)[\mathrm{M}+] \mathrm{m} / \mathrm{z} 843.3908$ found, 842.3910 calc.

Porphyrin (9). A total of $700 \mathrm{mg}(0.83 \mathrm{mmol})$ of porphyrin 8 and $1.9 \mathrm{~g}\left(4.1 \times 10^{-3} \mathrm{mmol}\right)\left[\mathrm{Au}(\mathrm{THT})_{2}\right] \mathrm{BF}_{4}$ were dissolved in $5 \mathrm{ml}$ chloroform. $193 \mu \mathrm{l}\left(1.6 \times 10^{-3} \mathrm{mmol}\right)$ of 2,6-lutidine was added and the reaction was heated to reflux. A gold mirror very rapidly deposited on the walls of the flask, and the reaction mixture turned reddish. After refluxing for three hours, the solution was evaporated to dryness. The residue was taken up in dichloromethane and purified through a silica column, eluting the free base porphyrin with dichloromethane and the desired red-orange band with $\mathrm{CH}_{2} \mathrm{Cl}_{2} /$ AcOEt (9/1).Yield: (602 $\mathrm{mg}, 70 \%)$. UV-Vis $\left(\mathrm{CH}_{2} \mathrm{Cl}_{2}, \mathrm{~nm}\right) \lambda_{\max }(\mathrm{nm}): 408\left(\varepsilon 3.1 \times 10^{5} \mathrm{~mol}^{-1} . \mathrm{L}^{\mathrm{cm}}{ }^{-1}\right), 526\left(1.2 \times 10^{4}\right) . \mathrm{NMR}\left({ }^{1} \mathrm{H}, \mathrm{CDCl}_{3}\right.$, $300 \mathrm{MHz}) \delta$ (ppm): 9.26-9.23 (m, 8H), 8.24-8.22 (d, 6H, J = 6.53 Hz), 8.16-8.14 (d, 2H, J=8.09 Hz), 7.90$7.83(\mathrm{~m}, 9 \mathrm{H}), 7.71-7.69(\mathrm{~d}, 2 \mathrm{H}, J=7.78 \mathrm{~Hz}), 3.83-3.78(\mathrm{t}, 1 \mathrm{H}, J=7.76 \mathrm{~Hz}), 3.51-3.49(\mathrm{~d}, 2 \mathrm{H}, J=8.09 \mathrm{~Hz})$, $1.55(\mathrm{~s}, 18 \mathrm{H})$. HRMS (ES+) [M+] m/z 1037.3326 found, 1037.3341 calc.

Porphyrin (10). $630 \mathrm{mg}$ (0.607 mmol) of gold porphyrin 9 was dissolved in $2 \mathrm{ml}$ TFA and heated at $70^{\circ} \mathrm{C}$ for seven hours. After removal of the solvent under reduced pressure, the product was dissolved in methanol and purified using exclusion size chromatography. Yield: (530 mg, 94\%). IR (ATR): $1634 \mathrm{~cm}^{-1}$ $(\mathrm{C}=\mathrm{O})$. UV-Vis $\left(\mathrm{CH}_{2} \mathrm{Cl}_{2}, \mathrm{~nm}\right) \lambda_{\max }(\mathrm{nm}): 408\left(\varepsilon 2.8 \times 10^{5} \mathrm{~mol}^{-1} . \mathrm{L}^{\mathrm{c}} \mathrm{cm}^{-1}\right), 526\left(1.3 \times 10^{4}\right) . \mathrm{NMR}\left({ }^{1} \mathrm{H}, \mathrm{DMSO}-\mathrm{d} 6\right.$, $300 \mathrm{MHz}) \delta(\mathrm{ppm}):$ 9.44-9.40 (m, 8H), 8.22-8.18 (m, 6H), 8.09-8.06 (d, $2 \mathrm{H}, J=8.13 \mathrm{~Hz}), 7.94-7.86(\mathrm{~m}$, $8 \mathrm{H}), 7.76-7.73(\mathrm{~d}, 2 \mathrm{H}, J=7.98 \mathrm{~Hz}), 3.92-3.88(\mathrm{t}, 1 \mathrm{H}, J=6.18 \mathrm{~Hz}), 3.71-3.69(\mathrm{~d}, 2 \mathrm{H}, J=5.85 \mathrm{~Hz})$. HRMS (ES+) [M+] m/z 925.2075 found, 925.2089 calc.

General procedure 2 (GP 2). Compound 10 was dissolved in EtOH and the carboxylic acid functions were activated into sodium carboxylates using 2 eq of $\mathrm{NaOH} .1 .2$ eq of the respective diammine(dinitro)platinum(II) complex was dissolved in Ethanol/Water (1/1) and added. The solution was stirred for $48 \mathrm{~h}$ at room temperature. The solvents were evaporated. The complexes were dissolved in DMF and precipitated with a saturated solution of $\mathrm{NaCl}$. The precipitated complexes AuP$\mathrm{PtNH}_{3}$, AuP-PtPy, AuP-PtCyDA were filtered, washed with water and dried.

AuP-PtNH 3 .According to GP2, $60 \mathrm{mg}\left(5.6 \times 10^{-2} \mathrm{mmol}\right)$ of gold porphyrin 10 was dissolved in $16 \mathrm{ml}$ $\mathrm{EtOH}, 4.5 \mathrm{mg}(0.11 \mathrm{mmol})$ of $\mathrm{NaOH}$ was added, combined with $23.74 \mathrm{mg}\left(67.2 \times 10^{-3} \mathrm{mmol}\right)$ of diamine(dinitro)platinum(II) dissolved in $12 \mathrm{ml}$ of a mixture $\mathrm{EtOH} / \mathrm{H} 2 \mathrm{O}(1 / 1)$. The mixture was stirred for $48 \mathrm{~h}$ at room temperature. The solvents were evaporated. The complex was dissolved in DMF and precipitated with a saturated solution of $\mathrm{NaCl}$. The precipitated complexAuP-PtNH${ }_{3}$ was filtered, 
washed with water and dried. Yield (58 mg, 90\%). IR (ATR): $1619 \mathrm{~cm}^{-1}(\mathrm{C}=\mathrm{O})$. UV-Vis $\left(\mathrm{CH}_{2} \mathrm{Cl}_{2}, \mathrm{~nm}\right) \lambda_{\max }$ $(\mathrm{nm}): 408\left(\varepsilon 2.8 \times 10^{5} \mathrm{~mol}^{-1} . \mathrm{L} . \mathrm{cm}^{-1}\right), 526\left(1.3 \times 10^{4}\right)$. NMR $\left({ }^{1} \mathrm{H}, \mathrm{DMSO}-\mathrm{d} 6,300 \mathrm{MHz}\right) \delta(\mathrm{ppm}): 9.35-9.28$ $(\mathrm{m}, 8 \mathrm{H}), 8.29-8.27(\mathrm{~d}, 6 \mathrm{H}, J=6.64 \mathrm{~Hz}), 8.26-8.17(\mathrm{~d}, 2 \mathrm{H}, J=8.01 \mathrm{~Hz}), 8.14-7.91(\mathrm{~m}, 9 \mathrm{H}), 7.82-7.79(\mathrm{~d}$, $2 \mathrm{H}, J=7.55 \mathrm{~Hz}), 4.38-4.34(\mathrm{t}, 1 \mathrm{H}, J=7.08 \mathrm{~Hz}), 4.36-4.28(\mathrm{br}, 6 \mathrm{H}), 3.55-3.54(\mathrm{~d}, 2 \mathrm{H}, J=5.31 \mathrm{~Hz}) . \mathrm{HRMS}$ (ES+) $[\mathrm{M}+] \mathrm{m} / \mathrm{z} 1151.2090$ found, 1151.2090 calc. Elem. Anal. Exp C, 48.69; H, 3.48; N, 6.35. calc C, 48.56; H, 3.61; N, 6.5 .

AuP-PtCyDA. According to GP2, $60 \mathrm{mg}\left(5.6 \times 10^{-2} \mathrm{mmol}\right)$ of gold porphyrin 10 was dissolved in $16 \mathrm{ml}$ $\mathrm{EtOH}, 4.5 \mathrm{mg}(0.11 \mathrm{mmol})$ of $\mathrm{NaOH}$ was added, combined with $27.66 \mathrm{mg}\left(63.8 \times 10^{-3} \mathrm{mmol}\right)$ of diamine(dinitro)platinum(II) dissolved in $12 \mathrm{ml}$ of a mixture $\mathrm{EtOH} / \mathrm{H} 2 \mathrm{O}(1 / 1)$. The mixture was stirred for $48 \mathrm{~h}$ at room temperature. The solvents were evaporated. The complex was dissolved in DMF and precipitated with a saturated solution of $\mathrm{NaCl}$. The precipitated complex AuP-PtCyDA was filtered, washed with water and dried. Yield (61 mg, 90\%). IR (ATR): $1626 \mathrm{~cm}^{-1}(\mathrm{C}=0) . \mathrm{UV}-\mathrm{Vis}\left(\mathrm{CH}_{2} \mathrm{Cl}_{2}, \mathrm{~nm}\right) \lambda_{\max }$ $(\mathrm{nm}): 408\left(\varepsilon 2.8 \times 10^{5} \mathrm{~mol}^{-1} . \mathrm{L} . \mathrm{cm}^{-1}\right), 526\left(1.3 \times 10^{4}\right)$. NMR ( $\left.{ }^{1} \mathrm{H}, \mathrm{DMSO}-\mathrm{d} 6,300 \mathrm{MHz}\right) \delta(\mathrm{ppm}): 9.34-9.30$ $(\mathrm{m}, 8 \mathrm{H}), 8.29-8.26(\mathrm{dd}, 6 \mathrm{H}, J=7.27,7.63 \mathrm{~Hz}), 8.18-8.15(\mathrm{~d}, 2 \mathrm{H}, J=8 \mathrm{~Hz}), 7.98-7.91(\mathrm{~m}, 9 \mathrm{H}), 7.81-7.78$ $(\mathrm{d}, 2 \mathrm{H}, J=8.36 \mathrm{~Hz}), 6.13-5.99(\mathrm{~m}, 2 \mathrm{H}), 5.45-5.32(\mathrm{~m}, 2 \mathrm{H}), 4.35-4.30(\mathrm{t}, 1 \mathrm{H}, J=6.56 \mathrm{~Hz}), 3.44-3.42(\mathrm{~d}$, $2 \mathrm{H}, J=6.82 \mathrm{~Hz}), 2.15-2.12(\mathrm{~m}, 2 \mathrm{H}), 1.86-1.82(\mathrm{t}, 2 \mathrm{H}, J=8.76 \mathrm{~Hz}), 1.48-1.46(\mathrm{~d}, 2 \mathrm{H}, J=9.28 \mathrm{~Hz}), 1.23-$ $1.21(\mathrm{~m}, 2 \mathrm{H}), 1.06-1.01(\mathrm{~m}, 2 \mathrm{H})$. HRMS (ES+) $[\mathrm{M}+] \mathrm{m} / \mathrm{z} 1231.2739$ found, 1231.2716 calc. Elem. Anal. Exp $C, 49.61 ; H, 3.79 ; N, 6.02$. calc $C, 49.3 ; H, 3.45 ; N, 6.34$.

AuP-PtPy. According to GP2, $60 \mathrm{mg}\left(5.6 \times 10^{-2} \mathrm{mmol}\right)$ of gold porphyrin 10 was dissolved in $16 \mathrm{ml}$ EtOH, $4.5 \mathrm{mg}(0.11 \mathrm{mmol})$ of $\mathrm{NaOH}$ was added, combined with $23.88 \mathrm{mg}\left(56 \times 10^{-3} \mathrm{mmol}\right)$ of diamine(dinitro)platinum(II) dissolved in a mixture of $2.5 \mathrm{ml} \mathrm{EtOH}$ and $17.5 \mathrm{ml} \mathrm{H} \mathrm{H}_{2} \mathrm{O}$. The solution was stirred for $48 \mathrm{~h}$ at room temperature. The solvents were evaporated. The complex was dissolved in DMF and precipitated with a saturated solution of $\mathrm{NaCl}$. The precipitated complex AuP-PtPy was filtered, washed with water and dried. Yield (61 mg, 90\%). IR (ATR): $1631 \mathrm{~cm}^{-1}(\mathrm{C}=0)$. UV-Vis $\left(\mathrm{CH}_{2} \mathrm{Cl}_{2}\right.$, nm) $\lambda_{\max }(\mathrm{nm}): 408\left(\varepsilon 2.8 \times 10^{5} \mathrm{~mol}^{-1} . \mathrm{L}^{\mathrm{cm}}{ }^{-1}\right), 526\left(1.3 \times 10^{4}\right) . \mathrm{NMR}\left({ }^{1} \mathrm{H}, \mathrm{DMSO}-\mathrm{d} 6,300 \mathrm{MHz}\right) \delta(\mathrm{ppm}):$ 9.33-9.30 (m, 8H), 8.52-8.50 (d, $1 \mathrm{H}, J=5.78 \mathrm{~Hz}), 8.27-8.25(\mathrm{~d}, 6 \mathrm{H}, J=6.39 \mathrm{~Hz}), 8.16-8.13(\mathrm{~d}, 2 \mathrm{H}, J=$ $7.92 \mathrm{~Hz}), 8.13-7.90(\mathrm{~m}, 9 \mathrm{H}), 7.83-7.80(\mathrm{~d}, 2 \mathrm{H}, J=7.92 \mathrm{~Hz}), 7.67-7.64(\mathrm{~d}, 1 \mathrm{H}, J=7.94 \mathrm{~Hz}), 7.55-7.50(\mathrm{t}$, $1 \mathrm{H}, J=7.12 \mathrm{~Hz}), 6.61-6.59(\mathrm{br}, 2 \mathrm{H}), 4.39-4.35(\mathrm{t}, 1 \mathrm{H}, J=6.75 \mathrm{~Hz}), 4.17-4.13(\mathrm{t}, 2 \mathrm{H}, J=5.44 \mathrm{~Hz}), 3.46-$ $3.44(\mathrm{~d}, 2 \mathrm{H}, J=5.44 \mathrm{~Hz})$. HRMS (ES+) [M+] m/z 1225.2269 found, 1225.2247 calc. Elem. Anal. Exp C, 49.16; H, 3.55; N, 5.92. calc C, 48.81; H, 3.17; N, 6.28.

Singlet oxygen detection. Singlet oxygen emission was detected through a double ruled grating SPEX monochromator (600 grooves/mm blazed at $1 \mu \mathrm{m}$ ) and a long-wave pass $(780 \mathrm{~nm}$ ). All spectra were 
measured in 4 faces quartz cuvettes. All the emission singlet oxygen luminescence have been displayed with the same absorbance (less than 0.2 ) with the lamp and photomultiplier correction.

\section{Biological experiments}

Cell culture. Human breast adenocarcinoma cells (MCF-7) (purchased from ATCC) were cultured in Dulbecco Eagle's Minimal Essential Medium (DMEM) supplemented with 10\% fetal bovine serum (FBS) and $1 \%$ penicillin/streptomycin (P/S). Adult Human Dermal Fibroblast cells (FS-68) were maintained in Roswell Park Memorial Institute (RPMI) medium supplemented with $10 \% \mathrm{FBS}$ and $1 \% \mathrm{P} / \mathrm{S}$. Both cell lines were allowed to grow in humidified atmosphere at $37{ }^{\circ} \mathrm{C}$ under $5 \% \mathrm{CO}_{2}$. For cytotoxic and phototoxic studies, the compounds (powder) are first diluted in DMSO at the concentration of $10 \mathrm{mM}$. Then, they are sonicated during 30 seconds and diluted at the required concentrations in culture medium of each cell line".

Cytotoxicity study. MCF-7 and FS-68 cells were seeded into 96-well plates at a density of $10^{3}$ cells $/ \mathrm{cm}^{2}$. One day after cell growth, cells were incubated with or without different concentrations of compounds (from 0.01 to $100 \mu \mathrm{M}$ ) for 3 days. After the incubation time, cells were incubated with $0.5 \mathrm{mg} \mathrm{mL}^{-1}$ MTT (3-(4,5- dimethylthiazol-2-yl)-2,5-diphenyltetrazoliumbromide)during $4 \mathrm{~h}$ to determine mitochondrial enzyme activity. Then, MTT precipitates were dissolved in ethanol/DMSO (1:1) solution and absorbance was measured at $540 \mathrm{~nm}$.

Phototoxicity assay. Both cell lines, MCF-7 and FS-68 cells, were seeded into 384-well plates at a density of $10^{3}$ cells $/ \mathrm{cm}^{2}$ and allowed to grow for $24 \mathrm{~h}$. Cells were incubated or not (control) with 0.5 $\mu \mathrm{M}$ concentration of compounds solution for $24 \mathrm{~h}$. After incubation, cells were exposed, or not, to light using mercury lamp of a fluorescence microscope at excitation ranges between $390-420 \mathrm{~nm}$ for $20 \mathrm{~min}$ $\left(39 \mathrm{~J} . \mathrm{cm}^{-2}\right)$. Two days after, MTT assay was performed to evaluate the phototoxic effect of compounds.

ROS production. The detection of ROS was performed during the phototoxicity experiment. Forty five minutes before irradiation, cells were incubated with $20 \mu \mathrm{M}$ concentration of DCFH 2 -DA(Cellular ROS Assay Kit, Abcam, USA). Cells were exposed to light using mercury lamp of a fluorescence microscope at excitation ranges between $390-420 \mathrm{~nm}$ for $20 \mathrm{~min}\left(39 \mathrm{~J} . \mathrm{cm}^{-2}\right)$. After irradiation, cells were washed and fluorescence emission of DCF was detected at $450 \mathrm{~nm}$ using fluorescent microscope. 


\section{References:}

(1).(a) Johnstone, T. C.; Suntharalingam, K.; Lippard, S. J. The Next Generation of Platinum Drugs: Targeted Pt(II) Agents, Nanoparticle Delivery, and Pt(IV) Prodrugs. Chem. Rev. 2016, 116, 3436-3486; (b) Galluzzi, L.; Senovilla, L.; Vitale, I.; Michels, J.; Martins, I.; Kepp, O.; Castedo, M.; Kroemer, G. Molecular mechanisms of cisplatin resistance. Oncogene 2011, 31, 1869; (c) Rabik, C. A.; Dolan, M. E. Molecular mechanisms of resistance and toxicity associated with platinating agents. Cancer Treatment Rev; 2007, 33, 9-23.

(2).(a) Fan, W.; Huang, P.; Chen, X. Overcoming the Achilles' heel of photodynamic therapy. Chem. Soc. Rev. 2016, 45, 6488-6519; (b) Celli, J. P.; Spring, B. Q.; Rizvi, I.; Evans, C. L.; Samkoe, K. S.; Verma, S.; Pogue, B. W.; Hasan, T. Imaging and Photodynamic Therapy: Mechanisms, Monitoring, and Optimization. Chem. Rev. 2010, 110, 2795-2838; (c) Ferreira dos Santos, A. I.; Queiroz de Almeida, D. R.; Ferreira Terra, L.; Baptista, M. c. S.; Labriola, L. Photodynamic therapy in cancer treatment - an update review. J. Cancer Metastasis Treat. 2019, 5, doi: 10.20517/2394-4722.2018.83.

(3).El-Far, M. A.; Pimstone, N. R. The interaction of tumour-localizing porphyrins with collagen, elastin, gelatin, fibrin and fibrinogen. Cell Biochem. Function 1985, 3, 115-119.

(4).Tjahjono, D. H. Porphyrin structure-based molecules for photodynamic therapy of cancer. Acta Pharm. Indones. 2006, 31, 1-12.

(5).(a) Lau, J. T. F.; Lo, P.-C.; Fong, W.-P.; Ng, D. K. P. A Zinc(II) Phthalocyanine Conjugated with an Oxaliplatin Derivative for Dual Chemo- and Photodynamic Therapy. J. Med. Chem. 2012, 55, 54465454; (b) Naik, A.; Rubbiani, R.; Gasser, G.; Spingler, B. Visible-Light-Induced Annihilation of Tumor Cells with Platinum-Porphyrin Conjugates. Angew. Chem. Int. Ed. 2014, 53, 6938-6941; (c) Lottner, C.; Bart, K.-C.; Bernhardt, G.; Brunner, H. Hematoporphyrin-Derived Soluble Porphyrin-Platinum Conjugates with Combined Cytotoxic and Phototoxic Antitumor Activity. J. Med. Chem. 2002, 45, 20642078; (d) Kim, Y.-S.; Song, R.; Hyun Kim, D.; Jun, M. J.; Sohn, Y. S. Synthesis, biodistribution and antitumor activity of hematoporphyrin-platinum(II) conjugates. Bioorg. Med. Chem. 2003, 11, 17531760; (e) Munakata, H.; Imai, H.; Nakagawa, S.; Osada, A.; Uemori, Y. Water-Soluble Porphyrins Appending Platinum(II) Complexes as Binders for Synthetic Nucleic Acid Polymers. Chem. Pharm. Bull. 2003, 51, 614-615; (f) Brunner, H.; Schellerer, K. M. New porphyrin platinum conjugates for the cytostatic and photodynamic tumor therapy. Inorg. Chim. Acta 2003, 350, 39-48.

(6).Longevial, J.-F.; El Cheikh, K.; Aggad, D.; Lebrun, A.; van der Lee, A.; Tielens, F.; Clément, S.; Morère, A.; Garcia, M.; Gary-Bobo, M.; Richeter, S. Porphyrins Conjugated with Peripheral Thiolato Gold(I) Complexes for Enhanced Photodynamic Therapy. Chem. Eur. J. 2017, 23, 14017-14026.

(7).(a) Schmitt, F.; Govindaswamy, P.; Süss-Fink, G.; Ang, W. H.; Dyson, P. J.; Juillerat-Jeanneret, L.; Therrien, B. Ruthenium Porphyrin Compounds for Photodynamic Therapy of Cancer. J. Med. Chem. 
2008, 51, 1811-1816; (b) Harvey, P. D.; Tasan, S.; Gros, C. P.; Devillers, C. H.; Richard, P.; Gendre, P. L.; Bodio, E. Ruthenium and Osmium Complexes of Phosphine-Porphyrin Derivatives as Potential Bimetallic Theranostics: Photophysical Studies. Organometallics 2015, 34, 1218-1227; (c) Gianferrara, T.; Bratsos, I.; lengo, E.; Milani, B.; Oštrić, A.; Spagnul, C.; Zangrando, E.; Alessio, E. Synthetic strategies towards ruthenium-porphyrin conjugates for anticancer activity. Dalton Trans. 2009, 10742-10756.

(8).(a) Sun, R. W.-Y.; Li, C. K.-L.; Ma, D.-L.; Yan, J. J.; Lok, C.-N.; Leung, C.-H.; Zhu, N.; Che, C.-M. Stable Anticancer Gold(III)-Porphyrin Complexes: Effects of Porphyrin Structure. Chem. Eur. J. 2010, 16, 30973113; (b) Sun, R. W.-Y.; Che, C.-M. The anti-cancer properties of gold(III) compounds with dianionic porphyrin and tetradentate ligands. Coord. Chem. Rev. 2009, 253, 1682-1691; (c) Tu, S.; Wai-Yin Sun, R.; Lin, M. C. M.; Tao Cui, J.; Zou, B.; Gu, Q.; Kung, H.-F.; Che, C.-M.; Wong, B. C. Y. Gold (III) porphyrin complexes induce apoptosis and cell cycle arrest and inhibit tumor growth in colon cancer. Cancer 2009, 115, 4459-4469; (d) Chen, H.; Yang, Q.; Sun, L.; Zhang, Z.; Tong, H.; Xu, A.; Wang, C. Synthesis and Biological Evaluation of Gold(III) Substituted Tetraarylporphyrin Chlorides as Anticancer Reagents. J. Chem.Res. 2011, 35, 190-194.

(9).(a) He, L.; Chen, T.; You, Y.; Hu, H.; Zheng, W.; Kwong, W.-L.; Zou, T.; Che, C.-M. A Cancer-Targeted Nanosystem for Delivery of Gold(III) Complexes: Enhanced Selectivity and Apoptosis-Inducing Efficacy of a Gold(III) Porphyrin Complex. Angew. Chem., Int. Ed. 2014, 53, 12532-12536; (b) Hu, D.; Liu, Y.; Lai, Y.-T.; Tong, K.-C.; Fung, Y.-M.; Lok, C.-N.; Che, C.-M. Anticancer Gold(III) Porphyrins Target Mitochondrial Chaperone Hsp60. Angew. Chem., Int. Ed. 2016, 55, 1387-1391; (c) Lum, C. T.; Wai-Yin Sun, R.; Zou, T.; Che, C.-M. Gold(iii) complexes inhibit growth of cisplatin-resistant ovarian cancer in association with upregulation of proapoptotic PMS2 gene. Chem. Sci. 2014, 5, 1579-1584; (d) Dandash, F.; Leger, D. Y.; Fidanzi-Dugas, C.; Nasri, S.; Bregier, F.; Granet, R.; Karam, W.; Diab-Assaf, M.; Sol, V.; Liagre, B. In vitro anticancer activity of new gold(III) porphyrin complexes in colon cancer cells. J. Inorg. Biochem. 2017, 177, 27-38; (e) Lammer, A. D.; Cook, M. E.; Sessler, J. L. Synthesis and anti-cancer activities of a water soluble gold(III) porphyrin. J. Porphyrins Phthalocyanines 2015, 19, 398-403; (f) Wang, Y.; He, Q.-Y.; Che, C.-M.; Tsao, S. W.; Sun, R. W.-Y.; Chiu, J.-F. Modulation of gold(III) porphyrin 1a-induced apoptosis by mitogen-activated protein kinase signaling pathways. Biochem. Pharmacol. 2008, 75, 1282-1291.

(10).Hu, D.; Liu, Y.; Lai, Y.-T.; Tong, K.-C.; Fung, Y.-M.; Lok, C.-N.; Che, C.-M. Anticancer Gold(III) Porphyrins Target Mitochondrial Chaperone Hsp60. Angew. Chem. Int. Ed. 2016, 55, 1387-1391.

(11).(a) Wilkinson, F.; Helman, W. P.; Ross, A. B. Quantum Yields for the Photosensitized Formation of the Lowest Electronically Excited Singlet State of Molecular Oxygen in Solution. J. Phys. Chem. Reference Data 1993, 22, 113-262; (b) Pineiro, M.; Carvalho, A. L.; Pereira, M. M.; Gonsalves, A. M. d. A. R.; Arnaut, L. G.; Formosinho, S. J. Photoacoustic Measurements of Porphyrin Triplet-State Quantum Yields and Singlet-Oxygen Efficiencies. Chem. Eur. J. 1998, 4, 2299-2307; (c) Pineiro, M.; Pereira, M. M.; 
Rocha Gonsalves, A. M. d. A.; Arnaut, L. G.; Formosinho, S. J. Singlet oxygen quantum yields from halogenated chlorins: potential new photodynamic therapy agents. J. Photochem. Photobiol. A 2001, 138, 147-157; (d) Obata, M.; Hirohara, S.; Tanaka, R.; Kinoshita, I.; Ohkubo, K.; Fukuzumi, S.; Tanihara, M.; Yano, S. In Vitro Heavy-Atom Effect of Palladium(II) and Platinum(II) Complexes of PyrrolidineFused Chlorin in Photodynamic Therapy. J. Med. Chem. 2009, 52, 2747-2753; (e) Horiuchi, H.; Terashima, K.; Sakai, A.; Suda, D.; Yoshihara, T.; Kobayashi, A.; Tobita, S.; Okutsu, T. The effect of central metal on the photodynamic properties of silylated tetraphenylporphyrin derivative. J. Photochem. Photobiol. A 2016, 321, 72-78; (f) Figueiredo, T. L. C.; Johnstone, R. A. W.; Sørensen, A. M. P. S.; Burget, D.; Jacques, P. Determination of Fluorescence Yields, Singlet Lifetimes and Singlet Oxygen Yields of Water-Insoluble Porphyrins and Metalloporphyrins in Organic Solvents and in Aqueous Media. Photochem. Photobiol. 1999, 69, 517-528.

(12).Brun, A. M.; Harriman, A.; Heitz, V.; Sauvage, J. P. Charge transfer across oblique bisporphyrins: two-center photoactive molecules. J. Am. Chem. Soc. 1991, 113, 8657-8663.

(13).(a) Singh, S.; Aggarwal, A.; Bhupathiraju, N. V. S. D. K.; Arianna, G.; Tiwari, K.; Drain, C. M. Glycosylated Porphyrins, Phthalocyanines, and Other Porphyrinoids for Diagnostics and Therapeutics. Chem. Rev. 2015, 115, 10261-10306; (b) Alonso, C.; Boyle, R. W., 17 Bioconjugates of Porphyrins and Related Molecules for Photodynamic Therapy. In Handbook of Porphyrin Science, pp 121-190.

(14).(a) Wilson, J. J.; Lippard, S. J. Synthetic Methods for the Preparation of Platinum Anticancer Complexes. Chem. Rev. 2014, 114, 4470-4495; (b) Bernhardt, G.; Biersack, B.; Bollwein, S.; Schobert, R.; Zoldakova, M. Terpene Conjugates of Diaminedichloridoplatinum(II) Complexes: Antiproliferative Effects in HL-60 Leukemia, 518A2 Melanoma, and HT-29 Colon Cancer Cells. Chem. Biodiversity 2008, 5, 1645-1659.

(15).Johnson, R. E.; Bacon, E. R. Novel dibenzo[d,f][1,3]dioxepines. Tetrahedron Lett. 1994, 35, 93279328.

(16).Dhara, S. C. A rapid method for the synthesis of cis-platine. Indian J. Chem. 1970, 8, 193-194.

(17).Segawa, H.; Azumi, R.; Shimidzu, T. Direct hydroxylation at the meso position of gold(III) tetraphenylporphyrin by nucleophilic addition: novel hydroxyphlorin derivatives. J. Am. Chem. Soc. 1992, 114, 7564-7565.

(18).Adler, A. D.; Longo, F. R.; Finarelli, J. D.; Goldmacher, J.; Assour, J.; Korsakoff, L. A simplified synthesis for meso-tetraphenylporphine. J. Org. Chem. 1967, 32, 476-476.

(19).Lindsey, J. S.; Schreiman, I. C.; Hsu, H. C.; Kearney, P. C.; Marguerettaz, A. M. Rothemund and Adler-Longo reactions revisited: synthesis of tetraphenylporphyrins under equilibrium conditions. $J$. Org. Chem. 1987, 52, 827-836.

(20).Chambron, J. C.; Heitz, V.; Sauvage, J.-P. Incorporation of gold(III) into porphyrins by disproportionation of $\left[\mathrm{Au}(\mathrm{tht})_{2}\right] \mathrm{BF}_{4}$. New J. Chem. 1997, 21, 237-240. 
(21).Silvers, S. J.; Tulinsky, A. The crystal and molecular structure of triclinic tetraphenylporphyrin. J. Am. Chem. Soc. 1967, 89, 3331-3337.

(22).Antipas, A.; Dolphin, D.; Gouterman, M.; Johnson, E. C. Porphyrins. 38. Redox potentials, charge transfer transitions, and emission of copper, silver, and gold complexes. J. Am. Chem. Soc. 1978, 100, 7705-7709.

(23).Eng, M. P.; Ljungdahl, T.; Andréasson, J.; Mårtensson, J.; Albinsson, B. Triplet Photophysics of Gold(III) Porphyrins. J. Phys. Chem. A 2005, 109, 1776-1784.

(24).(a) Escribano, E.; Font-Bardia, M.; Calvet, T.; Lorenzo, J.; Gamez, P.; Moreno, V. DNA binding studies of a series of cis-[Pt(Am) $\left.{ }_{2} \mathrm{X}_{2}\right]$ complexes $(\mathrm{Am}=$ inert amine, $\mathrm{X}=$ labile carboxylato ligand). Inorg. Chim. Acta 2013, 394, 65-76; (b) Xing, Y.; Lou, L.; Chen, X.; Ye, Q.; Xu, Y.; Xie, C.; Jiang, J.; Liu, W. Synthesis and cytotoxicity of diam(m)ineplatinum(II) complexes with 2,2-bis(hydroxymethyl)malonate as the leaving group. Bioorg. Med. Chem. Lett. 2012, 22, 2239-2241; (c) Ye, Q.-S.; Lou, L.-G.; Liu, Z.-Y.; Liu, W.-P.; Hou, S.-Q.; Chen, X.-Z.; Yu, Y. Synthesis, Characterization and Cytotoxicity of Diam(m)ineplatinum(II) Complexes Containing $\beta$-phenylisosuccinate Ligand. Arch. Pharm. Chem. Life Sci. 2007, $340,599-602$.

(25).(a) Suberu, J. O.; Romero-Canelón, I.; Sullivan, N.; Lapkin, A. A.; Barker, G. C. Comparative Cytotoxicity of Artemisinin and Cisplatin and Their Interactions with Chlorogenic Acids in MCF7 Breast Cancer Cells. ChemMedChem 2014, 9, 2791-2797; (b) Mirmalek, S. A.; Azizi, M. A.; Jangholi, E.; Yadollah-Damavandi, S.; Javidi, M. A.; Parsa, Y.; Parsa, T.; Salimi-Tabatabaee, S. A.; Ghasemzadeh kolagar, H.; Alizadeh-Navaei, R. Cytotoxic and apoptogenic effect of hypericin, the bioactive component of Hypericum perforatum on the MCF-7 human breast cancer cell line. Cancer Cell International 2016, 16, 3.

(26).Modica-Napolitano, J. S.; Aprille, J. R. Delocalized lipophilic cations selectively target the mitochondria of carcinoma cells. Adv. Drug Delivery Rev. 2001, 49, 63-70.

(27).(a) Tanielian, C.; Wolff, C. Porphyrin-Sensitized Generation of Singlet Molecular Oxygen: Comparison of Steady-State and Time-Resolved Methods. J. Phys. Chem. 1995, 99, 9825-9830; (b) Fernandez, J. M.; Bilgin, M. D.; Grossweiner, L. I. Singlet oxygen generation by photodynamic agents. J. Photochem. Photobiol. 1997, 37, 131-140.

(28).Pineiro, M.; Carvalho, A. L.; Pereira, M. M.; Gonsalves, A. M. d. A. R.; Arnaut, L. G.; Formosinho, S. J. Photoacoustic Measurements of Porphyrin Triplet-State Quantum Yields and Singlet-Oxygen Efficiencies. Chem. Eur. J. 1998, 4, 2299-2307.

(29).Poddutoori, P. K.; Lim, G. N.; Vassiliev, S.; D'Souza, F. Ultrafast charge separation and charge stabilization in axially linked 'tetrathiafulvalene-aluminum(III) porphyrin-gold(III) porphyrin' reaction center mimics. Phys. Chem. Chem. Phys. 2015, 17, 26346-26358. 
